Article

\title{
Ecological Variability and Carbon Stock Estimates of Mangrove Ecosystems in Northwestern Madagascar
}

\author{
Trevor G. Jones ${ }^{1,2, *}$, Harifidy Rakoto Ratsimba ${ }^{3}$, Lalao Ravaoarinorotsihoarana ${ }^{1}$, \\ Garth Cripps ${ }^{1}$ and Adia Bey ${ }^{1}$
}

1 Blue Ventures Conservation, Villa Bella Fiharena, Rue Gambetta, Lot 259, Toliara 601, Madagascar; E-Mails: lalao@blueventures.org (L.R.); garth@blueventures.org (G.C.); adia@blueventures.org (A.B.)

2 Integrated Remote Sensing Studio, Department of Forest Resources Management, 2424 Main Mall, University of British Columbia, Vancouver, BC V6T 1Z4, Canada

3 Department of Forestry, P.O. Box 175, University of Antananarivo, Antananarivo 101, Madagascar; E-Mail: rrharifidy@yahoo.fr

* Author to whom correspondence should be addressed; E-Mail: trevor@blueventures.org; Tel.: +1-315-557-0221.

Received: 6 December 2013; in revised form: 3 January 2014 / Accepted: 10 January 2014 / Published: 21 January 2014

\begin{abstract}
Mangroves are found throughout the tropics, providing critical ecosystem goods and services to coastal communities and supporting rich biodiversity. Despite their value, world-wide, mangroves are being rapidly degraded and deforested. Madagascar contains approximately $2 \%$ of the world's mangroves, $>20 \%$ of which has been deforested since 1990 from increased extraction for charcoal and timber and conversion to small to large-scale agriculture and aquaculture. Loss is particularly prominent in the northwestern Ambaro and Ambanja bays. Here, we focus on Ambaro and Ambanja bays, presenting dynamics calculated using United States Geological Survey (USGS) national-level mangrove maps and the first localized satellite imagery derived map of dominant land-cover types. The analysis of USGS data indicated a loss of 7659 ha $(23.7 \%)$ and a gain of 995 ha (3.1\%) from 1990-2010. Contemporary mapping results were $93.4 \%$ accurate overall (Kappa 0.9), with producer's and user's accuracies $\geq 85 \%$. Classification results allowed partitioning mangroves in to ecologically meaningful, spectrally distinct strata, wherein field measurements facilitated estimating the first total carbon stocks for mangroves in Madagascar. Estimates suggest that higher stature closed-canopy mangroves have average total vegetation carbon values of $146.8 \mathrm{Mg} / \mathrm{ha}( \pm 10.2)$ and soil organic
\end{abstract}


carbon of $446.2( \pm 36.9)$, supporting a growing body of studies that mangroves are amongst the most carbon-dense tropical forests.

Keywords: Madagascar; mangrove; carbon; Landsat; dynamics; Reducing Emissions from Deforestation and forest Degradation (REDD+); Payments for Ecosystem Services (PES)

\section{Introduction}

Mangroves are found in inter-tidal areas in over 120 countries between $30^{\circ} \mathrm{N}$ and $\mathrm{S}$ latitude and provide a broad range of important ecosystem goods (e.g., food; fuel; construction materials; medicine) and services (e.g., storm protection; erosive barriers; breeding, nesting, nursing and feeding grounds for marine, pelagic and terrestrial fauna; water filtration) for surrounding coastal communities [1-11]. Mangrove ecosystems also support high floral and faunal biodiversity [9,12-14] and sequester significant amounts of $\mathrm{CO}_{2}[15,16]$. While numerous studies have measured above-ground biomass in mangrove trees (e.g., [17-26]), comparatively few have quantified above- and below-ground carbon (C) pools, including soil (i.e., [15,27-34]); however, it is the deep, organic material enriched soils that contain the vast majority of $\mathrm{C}$ stocks [35-38]. Factoring in soil, mangroves have been found to be amongst the most carbon-dense forests in the tropics, with similar or greater above- and exceptionally larger below-ground stocks compared with the terrestrial systems reported in several studies [15,27,32-34,39]. Collectively, despite representing only about $0.7 \%$ of tropical forests, mangroves are thought to collectively store as much as 20 petagrams of $\mathrm{C}[15,17,40]$.

Despite their tremendous importance, within the last 50 years, global mangrove loss has been rapid and widespread, with estimates of 30\%-50\% since 1960 [41], 25\%-35\% from 1980-2000 [42-44] and $36 \%$ since 1990 [7]. Annual loss is estimated at around 1\%-2\%, exceeding the deforestation rates of inland tropical forests $[4,42,45,46]$. The primary anthropogenic drivers of loss include increasing coastal population and development, mounting economic pressures, small- to industrial-scale conversion to agriculture and aquaculture, over-extraction of forest products, and erosion, sedimentation and siltation from upstream intensive farming and terrestrial deforestation [47-54]. The principal natural drivers of loss include forest succession, hydrological dynamics and the impacts of extreme weather events (e.g., cyclones) and sea-level rise, which are projected to increase in frequency and magnitude, due to climate change [4,8,47,53,55-58]. Degradation and deforestation result in substantial greenhouse gas emissions if deep organic soil layers are disturbed [15,59-61]. Much of the world's remaining mangroves are already degraded, and if current trends continue, most of the remaining extent could become functionally valueless within the 21 st century $[41,45,62]$.

Globally, the collective importance and value of mangrove ecosystems is receiving an increasing amount of attention [16,63-67]. Owing to their value and rate of loss, up-to-date information representing the extent and status is critical for effective management and decision making [11]. Employing remotely sensed data for mapping and monitoring mangrove ecosystems is already well established [11,68]. Maps produced from remotely sensed data can enable the partitioning of mangrove ecosystems by ecological differences and statistically distinct $\mathrm{C}$ stock values. Of particular note, Landsat imagery is freely available, offers $>40$ years of data and has proven critical for both 
locating and quantifying mangrove extent and loss and partitioning mangrove ecosystems to estimate C stocks [40,69-79].

Madagascar contains Africa's fourth largest extent of mangroves and, as of 2005, represented 2\% of the global distribution, covering approximately $2800 \mathrm{~km}^{2}$ [7,40,80]. In keeping with global trends, Madagascar's mangroves are being rapidly degraded and, in some areas, completely deforested from logging for commercial timber and charcoal production, land-use conversion to agriculture and commercial small-scale (artisanal) and large-scale aquaculture. Anthropogenic loss is particularly significant in Madagascar's second largest mangrove ecosystem in the northwestern Ambanja and Ambaro bays. Existing national-level maps include contemporary and historical areal extents for mangroves and provide the information required for quantifying the dynamics; however, these data lack the detail required for comprehensive ecosystem characterization and estimation of $\mathrm{C}$ stocks for distinct mangrove types. While there have been several localized mangrove mapping efforts in Madagascar for Mahajamba Bay (i.e., [81-83]), Betsiboka Bay [84] and the Mangoky Delta [85], there are none published for Ambanja and Ambaro bays. Additionally, no studies have reported above- and below-ground C stocks, including soil, for any of Madagascar's mangroves. Here, we use existing national-level maps to calculate the long-term dynamics and employ Landsat data to produce the first ever localized map (circa 2010) of mangrove ecosystems and surrounding terrestrial land-cover types for Ambanja and Ambaro bays. Using the localized map to partition the mangroves in to ecologically meaningful strata, we also present the first estimates of total $\mathrm{C}$ stocks for Malagasy mangroves and compare them with published values for other terrestrial forest types.

\section{Experimental Section}

\subsection{Study Area}

The area of interest (AOI) includes the combined marine and terrestrial extent of Ambanja and Ambaro bays in northwest Madagascar (centered on latitude $48^{\circ} 30^{\prime}$ East, longitude $13^{\circ} 26^{\prime}$ South) (Figure 1). Both bays are lined with extensive mangroves, collectively totaling approximately 26,000 hectares (ha). In Madagascar, the AOI mangroves are surpassed in area only by Mahajamba Bay [86]. In the AOI, the semi-diurnal tidal range varies between maximums of 3-3.5 m, and the climate is sub-humid tropical, typified by a relatively dry and cool period from May-October and comparatively hotter and wetter weather influenced by periodic cyclones from November-April [87]. Alluvial and lake deposits predominantly characterize the underlying geology, and the comparative abundance of rainfall and freshwater contributes to higher stature mangrove trees than further south $[80,88]$. In the AOI and throughout coastal Madagascar, communities are extremely vulnerable to climate change, and mangroves are vital to their present and future wellbeing. The range, frequency and magnitude of anthropogenic activities within mangroves continue to rise for numerous reasons, including a lack of governance and increasing population. 
Figure 1. The area of interest includes the combined marine and terrestrial extent encompassed by a seven kilometer coastal buffer of Ambanja and Ambaro bays. One-hundred ninety-one classification reference areas and 55 mangrove carbon plots are shown. The background image is the near-infrared band (i.e., band 4) from a (Global Land Survey) GLS 2010 Landsat image, projected to Universal Transverse Mercator (UTM).

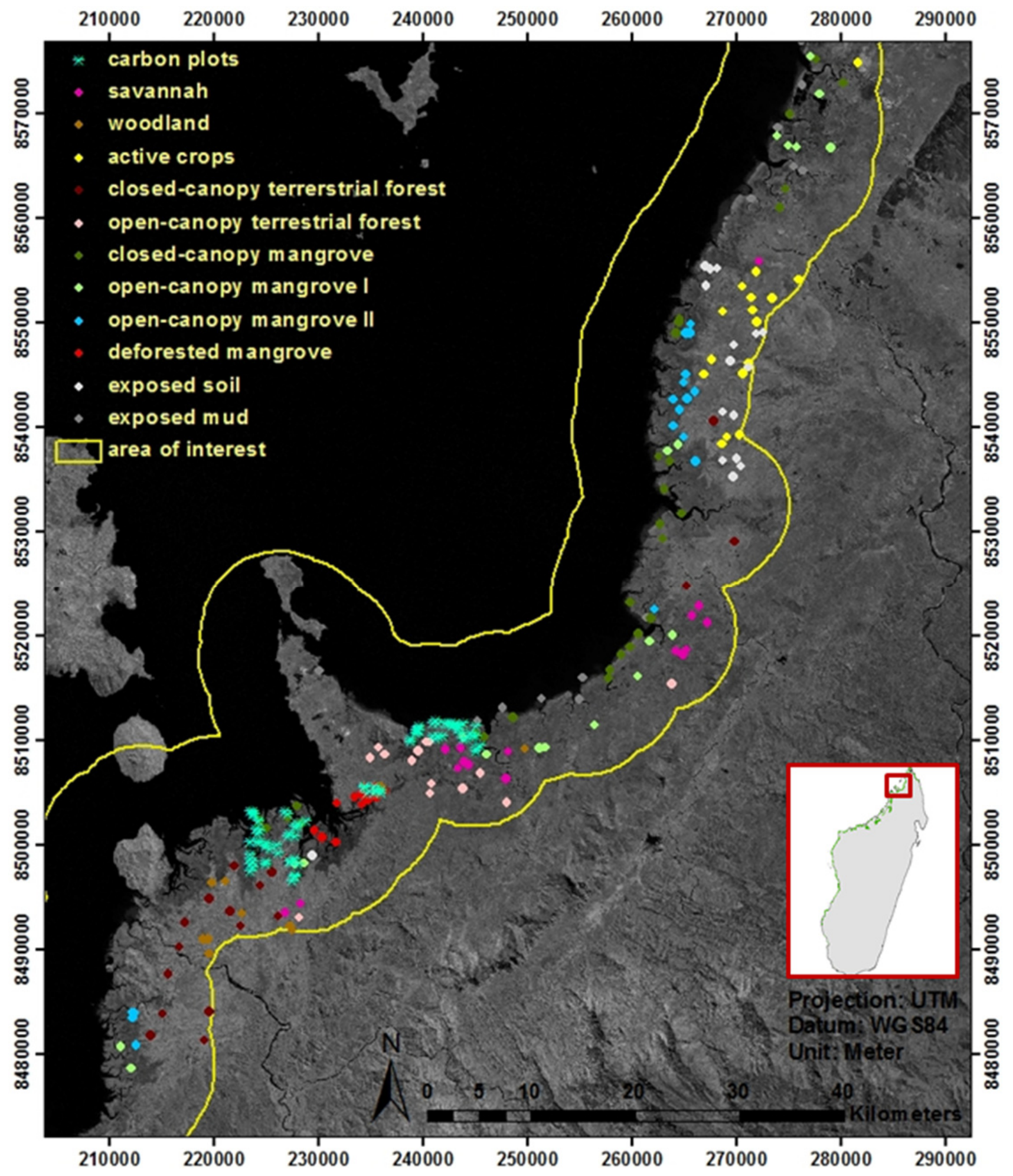




\subsection{Inventory of Existing Mangrove Maps and Assessment of Mangrove Dynamics}

National-level datasets providing mangrove coverage over the AOI include maps produced by or described in Mayaux et al. [89], the Critical Ecosystem Partnership Fund (CEPF) Madagascar Mapping Project [90], Harper et al. [91], Giri and Muhlhausen [80] and Giri [86]. Mayaux et al. [89] used 1-km Satellite Pour l'Observation de la Terre (SPOT) data to map six dominant vegetation cover types, including mangroves, representing coverage in 1998/1999. The CEPF [90] used Moderate Resolution Imaging Spectroradiometer (MODIS) and Landsat data to produce a 15-class vegetation map circa 2001, including a mangrove class. Harper et al. [91] used Landsat data to map forest cover, including mangroves, for 1973, 1990 and 2000. Using methods detailed in Giri and Muhlhausen [80], Chandra Giri and colleagues at the United States Geological Survey (USGS) produced Landsat-derived maps representing two classes (i.e., mangrove and non-mangrove) for 1973, 1990, 2000, 2005 and 2010 [86]. To determine which dataset provided the most representative mangrove coverage, all maps were compared with reference to Landsat composites, finer spatial resolution imagery viewable through Google Earth and preliminary field observations. The coverage deemed most representative was used to calculate the estimates for mangrove dynamics (i.e., gain, loss and persistence) within the AOI.

\subsection{Acquisition and Pre-Processing of Remotely Sensed Data}

A Global Land Survey (GLS) Landsat Enhanced Thematic Mapper (ETM)+ scene (path/row: 159/69) was acquired from the USGS Earth Resources Observation and Science Center [92] providing wall-to-wall coverage over the AOI from June 9 2010. GLS data are prepared by the USGS and the National Aeronautics and Space Administration, providing mostly cloud-free, 30-meter (m) spatial resolution, orthorectified (i.e., to a Shuttle Radar Topography Mission (SRTM) digital elevation model (DEM)) Landsat scenes for multiple eras (e.g., 2000, 2005 and 2010 editions) [93]. The Landsat scene was atmospherically corrected using the Cos(t) model, which estimates the effects of absorption by atmospheric gases and Rayleigh scattering, removes systematic atmospheric haze and converts image units to at-surface reflectance [94].

Based on distance to coastline as a mangrove habitat requirement [75,77,95], a 7-km coastal buffer mask was applied. To further exclude areas where mangrove habitat and associated ecosystems were observed not to exist, portions of the imagery $>30 \mathrm{~m}$ in elevation were removed using an SRTM DEM height mask. SRTM data have previously been associated with field measurements to provide reasonable estimates of mangrove forest canopy heights (e.g., [96-98]). Reducing the extent of the area to be classified through masking has been shown to raise accuracy by decreasing spectral variation and confusion amongst the potential range of mapped classes [39]. Preliminary field-recorded height measurements, existing mangrove maps and finer spatial resolution satellite imagery viewable in Google Earth were utilized to determine the thresholds for isolating low-lying coastal scene components. 


\subsection{Definition and Refinement of Mangrove and Surrounding Land-Cover Categories}

Using Landsat ETM+ bands $1-5$ and 7 as input, an unsupervised iterative self-organizing classification algorithm (i.e., ISOCLUST) was employed to group pixels into clusters representing prominent spectral components and remove areas dominated by water and shadow. Unsupervised classification is a common preliminary step in the detection and delineation of mangrove and closely related ecosystem types, having been employed in numerous studies [40,78,80,98-101]. Existing national-level land-cover and mangrove maps and high spatial resolution imagery viewable through Google Earth were referenced to iteratively aggregate and label clusters according to suspected dominant mangrove and other land-cover types (Table 1). Throughout the remote sensing literature, the definition of "mangrove" is extremely variable, at times referring to individual trees, mangrove-related flora or entire ecosystems [11,102]. Our classes are based on dominance by true mangroves, defined by Tomlinson [103] as salt-tolerant halophytic trees and shrubs occurring exclusively in the tidal/inter-tidal zone. Mangrove sub-class labels were initially assigned based on broad canopy-cover categories thought to represent distinct stature and density characteristics.

Table 1. Mapped classes and descriptions.

\begin{tabular}{|c|c|c|}
\hline Class & Description of typical constituents & $\begin{array}{l}\text { Class can also } \\
\text { include }\end{array}$ \\
\hline Savannah & mosaic of dry grass, exposed soil and extremely sparse trees/shrubs & $\begin{array}{l}\text { senesced rice; } \\
\text { reeds }\end{array}$ \\
\hline Woodland & mosaic of dry grass and scattered trees/shrubs; canopy $<30 \%$ closed & $\begin{array}{l}\text { orchard } \\
\text { agriculture }\end{array}$ \\
\hline Active cultivation & sugar cane, rice, reeds & \\
\hline $\begin{array}{l}\text { Closed-canopy } \\
\text { terrestrial forest }\end{array}$ & closed-canopy terrestrial forest; canopy $>60 \%$ closed & \\
\hline $\begin{array}{l}\text { Open-canopy } \\
\text { terrestrial forest }\end{array}$ & open-canopy terrestrial forest; canopy $30 \%-60 \%$ closed & \\
\hline $\begin{array}{l}\text { Closed-canopy } \\
\text { mangrove }\end{array}$ & tall, mature stands; canopy $>60 \%$ closed & $\begin{array}{l}\text { extremely dense } \\
\text { younger stands }\end{array}$ \\
\hline $\begin{array}{l}\text { Open-canopy } \\
\text { mangrove I }\end{array}$ & $\begin{array}{l}\text { young, short-medium trees; canopy } 30 \%-60 \% \text { closed; influenced by } \\
\text { background soil/mud }\end{array}$ & $\begin{array}{l}\text { naturally open; } \\
\text { very degraded tall }\end{array}$ \\
\hline $\begin{array}{l}\text { Open-canopy } \\
\text { mangrove II }\end{array}$ & $\begin{array}{l}\text { stunted short trees, very sparse; canopy } \geq 10 \% \text { closed; dominated by } \\
\text { background soil/mud }\end{array}$ & \\
\hline $\begin{array}{l}\text { Deforested } \\
\text { mangrove }\end{array}$ & $\begin{array}{l}\text { mosaic of stumps, scattered trees; canopy }<30 \% \text { closed; greatly } \\
\text { influenced by exposed soil/mud }\end{array}$ & \\
\hline Exposed soil & $\begin{array}{l}\text { inactive agri/aquacultural fields; extremely patchy savannah; } \\
\text { extremely dry tanne (mud-flats) }\end{array}$ & \\
\hline Exposed mud & $\begin{array}{l}\text { mangrove/ocean interface; river sediment; wet tannes (mud-flats); } \\
\text { inactive aquaculture ponds }\end{array}$ & \\
\hline
\end{tabular}

To confirm and refine initial class definitions and ensure representative classification, reference data were acquired in February, 2012, during a field survey conducted using a stratified random sampling design, wherein potential plot locations were randomly targeted within mangrove and surrounding land-cover types. A total of $22100 \times 100 \mathrm{~m}$ (i.e., hectare-sized) nested classification 
reference areas were established within mangroves, wherein height, species dominance, stature, age, density, canopy-cover, micro-relief, level of tidal-inundation and the impact of natural and anthropogenic disturbance were estimated qualitatively. Hectare-sized plots were used to ensure that reference areas representing different mangrove ecosystem types could be confidently located within the Landsat image. Within each reference plot, the diameter at 130 or 30 centimeters $(\mathrm{cm})$ (depending on the tree height), height and crown dimensions were measured using a diameter tape and a Vertex hypsometer for representative examples of each mangrove species present in five systematically located $10 \times 10 \mathrm{~m}$ sub-plots. In each sub-plot, a densiometer was also used to quantify canopy-cover, and litter, understory, regeneration, stumps and standing dead-wood were inventoried. Additional reference areas were established within all non-mangrove classes (see Table 1), wherein extensive field notes and photographs recorded the variability and level of representation. Within all reference areas, geographic coordinates were recorded using a Garmin GPSmap 62sc global positioning system (GPS) unit, which averaged the location in the center for the duration of sampling. Following the fieldwork, through exploiting the familiarity gained with the appearance and location of target mangrove and surrounding land-cover types, additional areas were located to augment field-collected data with reference to imagery viewable in Google Earth. In total, $7190 \times 90 \mathrm{~m}(3 \times 3$ pixel $)$ reference areas representing mangrove types and 120 representing non-mangrove classes were delineated. For all classes, at least $33 \%$ of the classification reference data was randomly withheld to assess map accuracy.

\subsection{Image Classification}

The maximum likelihood (ML) algorithm was employed for pixel-based classification of Landsat bands 1-5 and 7. Numerous studies support ML as an effective and robust algorithm for classifying mangrove habitat with medium spatial resolution remotely sensed data [77,79,81,97,104-109]. Accuracy was quantitatively assessed using a confusion matrix to cross-tabulate mapped classes against independent validation data. In addition, the Kappa index of agreement was used to assess the extent to which the classification was better than random [110]. Adopting an approach described by Giri and Muhlhausen [80] and Giri et al. [40], the classified map was also divided into a geographically explicit grid in Google Earth, facilitating comparisons with existing maps and finer spatial resolution satellite imagery to identify additional classification error. The classified map was further compared with the best available mangrove coverage data for the AOI, making reference to Landsat color composites, finer spatial resolution imagery viewable through Google and field observations.

\subsection{Mangrove Carbon Stocks}

To calculate biomass and, subsequently, to estimate $\mathrm{C}$ stocks, field surveys were conducted in April-May and August-September, 2012, using a modified version of the measurement protocol outlined in Kauffman and Donato [39], employing a stratified sampling design, wherein plots were systematically located within dominant mangrove cover types. Mangrove strata were defined based on the results of ML classification. Fine spatial resolution imagery viewable in Google Earth was used to eliminate potential plots based on inaccessibility, proximity to class transitions and map error. A total 
of 55 rectangular nested carbon plots were established (Figure 1). Plots had a default size of $10 \times 10 \mathrm{~m}$, but were enlarged to $20 \times 20 \mathrm{~m}$ if required, to capture ecological variability. All C plots consisted of an inner plot within the main plot (i.e., nested design). Within the inner plot ( $5 \times 5$ or $10 \times 10 \mathrm{~m}$, depending on the plot size), all the trees with a diameter $<5 \mathrm{~cm}$ were measured. Throughout the entire plot $(10 \times 10$ or $20 \times 20 \mathrm{~m}$, depending on the plot size $)$, all the trees with a diameter $>5 \mathrm{~cm}$ were measured. Tree measurements included species type, height, diameter (at 130 or $30 \mathrm{~cm}$, depending on height) and the quality of the lead stem, from which plot-level stature, species dominance, density and biomass were derived. Information about the geomorphology (i.e., location, topography) and site conditions (e.g., salinity) was also collected. Canopy-cover was systematically estimated to further assess mangrove labels. For standing dead trees and stumps, heights and diameters were measured to document degradation. Regeneration (i.e., seedlings and saplings), lying-dead wood, leaf-litter, epiphytes and the understory were inventoried, but not quantitatively sampled, as their carbon pools were considered negligible [27]. Soil depth was measured randomly in each quadrat and at the plot-center with a 3-m metal rod. Soil samples were extracted at the plot-center using a soil corer at $0-15,15-30,30-50,50-100$ and $100-150 \mathrm{~cm}$. Plot locations were recorded at the plot center using a Garmin GPSmap 62sc GPS unit.

The strong allometric relationships between tree height, diameter at breast height and biomass were used to estimate above-ground biomass and to calculate carbon stocks [111,112]. Equations were selected following a thorough review of the literature and expert advice (Table 2). The below-ground biomass of trees was calculated using a generalized equation developed by Komiyama et al. [113]. The biomass of standing dead wood was calculated using equations in Kauffman and Donato [39]. The bulk density (i.e., oven dry sample mass $(\mathrm{g}) /$ volume of the sample $\left.\left(\mathrm{cm}^{3}\right)\right)$ and the organic carbon content of the soil samples were determined by the Laboratoire des Radio Isotopes (LRI) of the University of Antananarivo in Madagascar's capitol city of Antananarivo. To establish the mass of the soil samples divided by the sample volume (i.e., bulk density: $\mathrm{g} / \mathrm{cm}^{3}$ ), the LRI first placed wet soil samples in a ventilated oven at $105{ }^{\circ} \mathrm{C}$ for $24 \mathrm{~h}$. The weight of dried samples and empty soil containers were then recorded and each oven-dried sample's mass divided by the sample's volume. To determine soil organic carbon (SOC) content, a modified Walkley-Black method was employed, which involved oxidizing soil organic matter without external heat using an $\mathrm{H}_{2} \mathrm{SO}_{4}$ solution and potassium dichromate $\left(\mathrm{K}_{2} \mathrm{Cr}_{2} \mathrm{O}_{7}\right)$. Further details on this modified Walkley-Black approach are available in Schumacher [114], Mikhailova et al. [115], De Vos et al. [116], Meersmans et al. [117] and Simpson [118]. 
Table 2. Allometric equations employed for calculating above-ground biomass (B). $\mathrm{dbh}$ refers to diameter at breast height; $\mathrm{D}$ represents diameter; $\mathrm{H}$ stands for height; $\mathrm{p}=$ wood density.

\begin{tabular}{llcc}
\hline Species & Allometric equation & Wood density [119] & References \\
\hline Avicennia marina & $\mathrm{B}=0.1848 \times \mathrm{dbh}^{2.3524}$ & 0.661 & {$[120]$} \\
Bruguiera gymnorrhiza (leaves) & $\mathrm{B}=0.0679 \times \mathrm{dbh}^{1.4914}$ & 0.741 & {$[121]$} \\
Bruguiera gymnorrhiza $(\mathrm{stem})$ & $\mathrm{B}=0.464 \times\left(\mathrm{dbh}^{2} \times \mathrm{H}\right)^{0.94275} \times \mathrm{p}$ & 0.741 & {$[22]$} \\
Ceriops tagal $(\mathrm{dbh}$ 2-18 cm) & $\mathrm{B}=10^{-0.7247} \times \mathrm{dbh}^{2.3379}$ & 0.803 & {$[121]$} \\
Ceriops tagal $(\mathrm{dbh} 18-25 \mathrm{~cm})$ & $\mathrm{B}=10^{-0.494} \times \mathrm{dbh}^{2.056}$ & 0.803 & {$[122]$} \\
Heritiera littoralis (leaves) & $\mathrm{B}=0.0679 \times \mathrm{dbh}^{1.4914}$ & 1.074 & {$[121]$} \\
Heritiera littoralis $($ stem) & $\mathrm{B}=0.464 \times\left(\mathrm{dbh}^{2} \times \mathrm{H}\right)^{0.94275} \times \mathrm{p}$ & 1.074 & {$[22]$} \\
Lumnitzera racemosa & $\mathrm{B}=0.0214 \times\left(\mathrm{dbh}^{2} \times \mathrm{H}\right)^{1.05655} \times \mathrm{p}$ & 0.565 & {$[22]$} \\
Rhizophora mucronata $($ leaves) & $\mathrm{B}=0.0139 \times \mathrm{D}^{2.1072}$ & 0.867 & {$[121]$} \\
Rhizophora mucronata $($ root) & $\mathrm{B}=0.0068 \times \mathrm{dbh}^{3.1353}$ & 0.867 & {$[121]$} \\
Rhizophora mucronata (stem) & $\mathrm{B}=0.0311 \times\left(\mathrm{dbh}^{2} \times \mathrm{H}\right)^{1.00741} \times \mathrm{p}$ & 0.867 & {$[22]$} \\
Sonneratia alba & $\mathrm{B}=0.0825 \times\left(\mathrm{dbh}^{2} \times \mathrm{H}\right)^{0.89966} \times \mathrm{p}$ & 0.78 & {$[22]$} \\
Xylocarpus granatum & $\mathrm{B}=0.0830 \times\left(\mathrm{dbh}^{2} \times \mathrm{H}\right)^{0.89806} \times \mathrm{p}$ & 0.7 & {$[22]$} \\
\hline
\end{tabular}

\section{Results and Discussion}

\subsection{Overview of Existing Mangrove Maps}

Comparisons confirmed that the USGS-produced maps [86] offered the most representative historical and contemporary areal estimates of Ambanja and Ambaro bays' mangroves. Owing to the use of moderate spatial resolution Landsat data, the USGS maps provided greater detail than those derived from coarse resolution SPOT data by Mayaux et al. [89]. Other national-level assessments involved Landsat data, but their scope included numerous terrestrial forest classes (i.e., [90,91]), resulting in less representative mangrove classes. The USGS products were the only maps to focus solely on mangrove coverage and to provide relatively contemporary (i.e., 2010) coverage; all others represented multiple forest classes for time periods nearly or more than 10 years earlier. For further details associated with comparisons between Madagascar's existing mangrove datasets, see Giri and Muhlhausen (2008) [80]. Using USGS-produced 1990, 2000 and 2010 maps as input, the analysis of historic dynamics indicated that from 1990-2000, Ambanja and Ambaro bays' mangroves decreased by 2473 ha (7.7\%) and gained 466 ha (1.4\%). From 2000-2010, there were 5672 ha of loss (18.7\%) and 1104 ha of gain (3.3\%). Taken collectively, from 1990-2010, mangroves experienced a loss of 7659 ha (23.7\%), a gain of 995 ha $(3.1 \%)$ and persistence over 24,669 ha (76.3\%) (Figure 2). 
Figure 2. Mangrove dynamics from 1990-2000 and 2000-2010. Persistence, loss and gain were calculated using national-level mangrove maps produced by the United States Geological Survey (USGS).

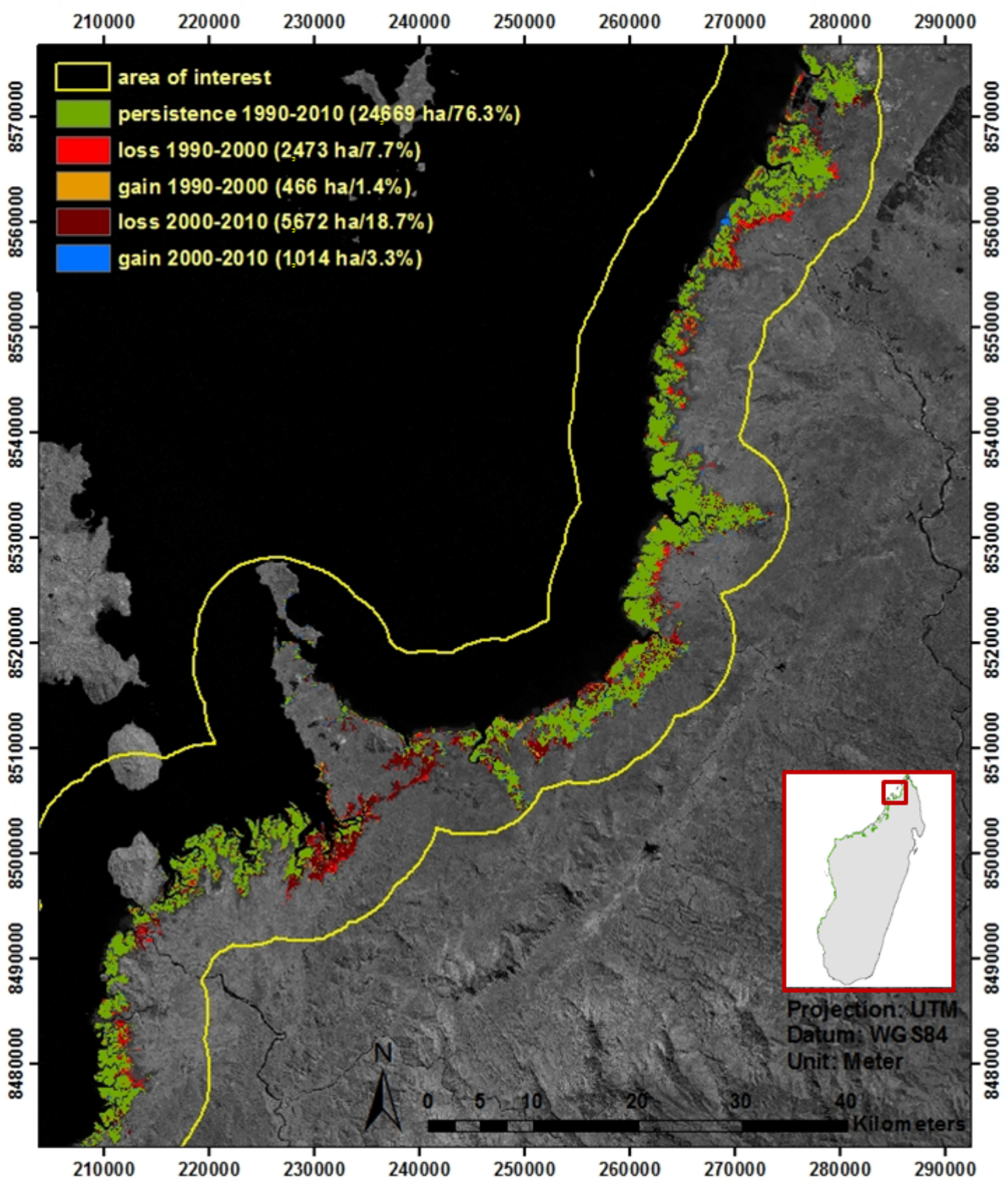




\subsection{Spectral Separability and Classification Results}

Results indicate that at certain wavelengths, all mapped classes were spectrally distinguishable (Figure 3). The near-infrared (NIR) and short-wave infrared (SWIR) were particularly useful for representing mangrove classes. Established properties of vegetation in the NIR and SWIR help to provide an ecologically meaningful context for the observed separability. In band 4 (i.e., NIR: 0.76-0.90 micrometers $(\mu \mathrm{m})$ ), spectral contrast was likely driven by the transitional red-edge, internal vegetation structure and leaf dry-matter content [11,77,122,123]. Increased reflectance in the NIR due to a higher concentration of vegetation was particularly evident for closed-canopy mangroves. For bands 5 (i.e., SWIR: 1.55-1.75 $\mu \mathrm{m}$ ) and 7 (SWIR: 2.08-2.35 $\mu \mathrm{m}$ ), spectral differences were likely explained by vegetation and soil moisture content and, to a lesser degree, various other canopy-level biogeochemical constituents [124]. Differences in moisture content, especially in band 7, were able to discern between all mangrove types. In addition to distinguishing amongst mangrove classes, our findings support previous work demonstrating that measurements at SWIR wavelengths can further differentiate mangroves from terrestrial vegetation [125]. In contrast to Kuenzer et al. [11], there were additional differences between all mangrove types in visible band 3 (i.e., red: $0.63-0.69 \mu \mathrm{m}$ ). Open-canopy II mangroves could also be distinguished from other mangrove types using visible bands 1 (i.e., blue: $0.45-0.52 \mu \mathrm{m}$ ) and 2 (i.e., green: $0.53-0.61 \mu \mathrm{m}$ ); however, confusion with exposed soil and mud was high at these wavelengths. Subtle differences in moisture content in the SWIR provided the increased separability required to distinguish open-canopy II and bare soil classes.

Figure 3. The mean spectral value ( \pm 1 standard deviation) of mapped classes.

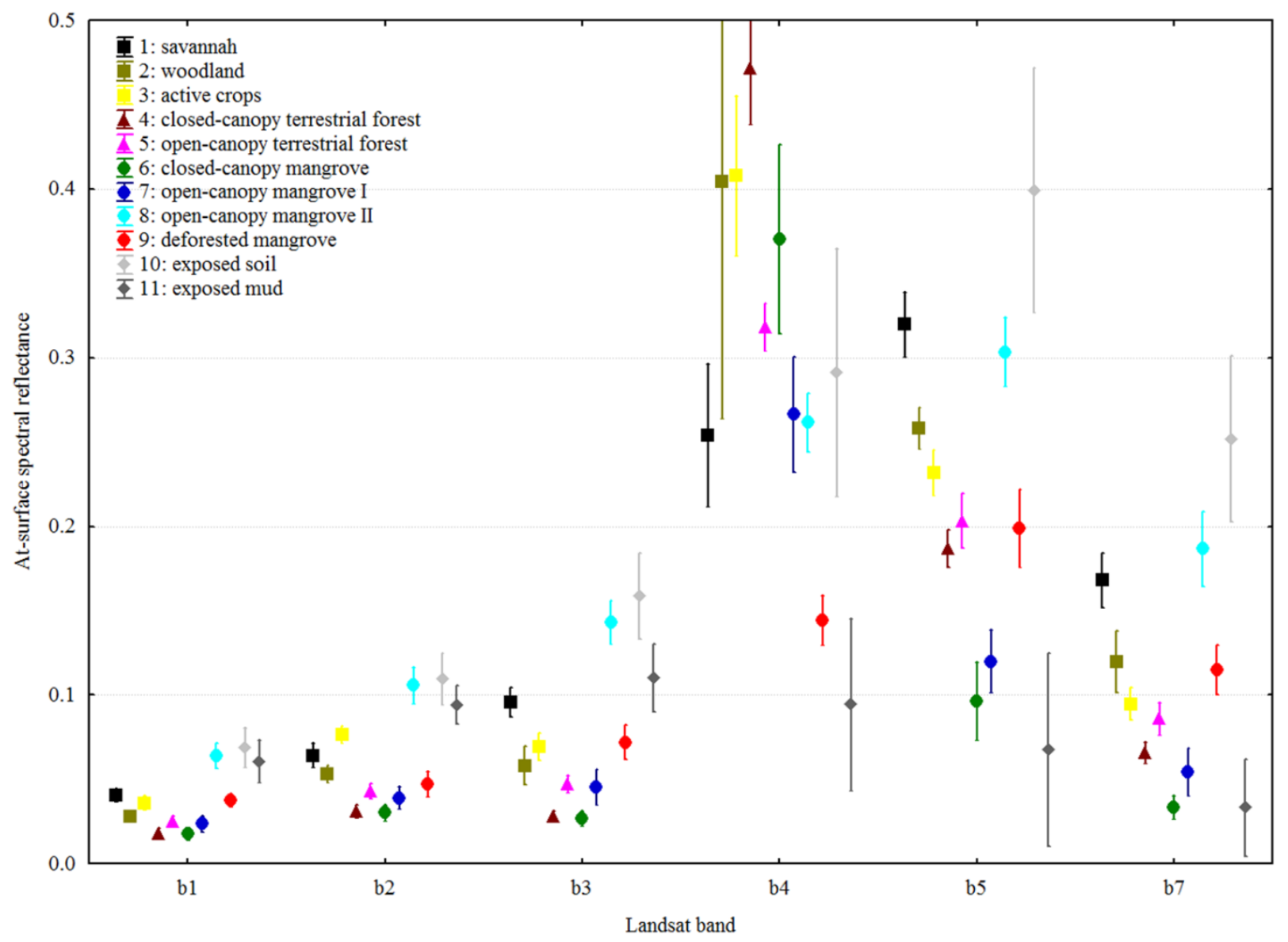


ML classification results indicate 14,015 ha of closed-canopy, 26,192 ha of open-canopy I and 5473 ha of open-canopy II mangroves, totaling 45,680 ha of mangroves in the AOI (Figure 4). Results further indicate nearly 1000 ha of deforested mangroves found disproportionately near and on the peninsula separating Ambanja and Ambaro bays. Overall map accuracy was 93.4\% (Kappa 0.9), with all mangrove classes mapped with producer's and user's accuracies $\geq 85 \%$ (Table 3). Mangrove class error was driven by a few incidents of confusion between closed-canopy and open-canopy I. Inter-mangrove class confusion can be explained by the similarities in spectral properties exhibited by extremely dense young and closed-canopy stands and naturally open and/or highly degraded tall and open-canopy I stands. While confusion with other vegetation classes (e.g., terrestrial forest) has been reported as a common source of classification error [68], our results indicate this was, in large part, avoided.

Figure 4. Results from the maximum likelihood classification of Landsat GLS 2010 data.

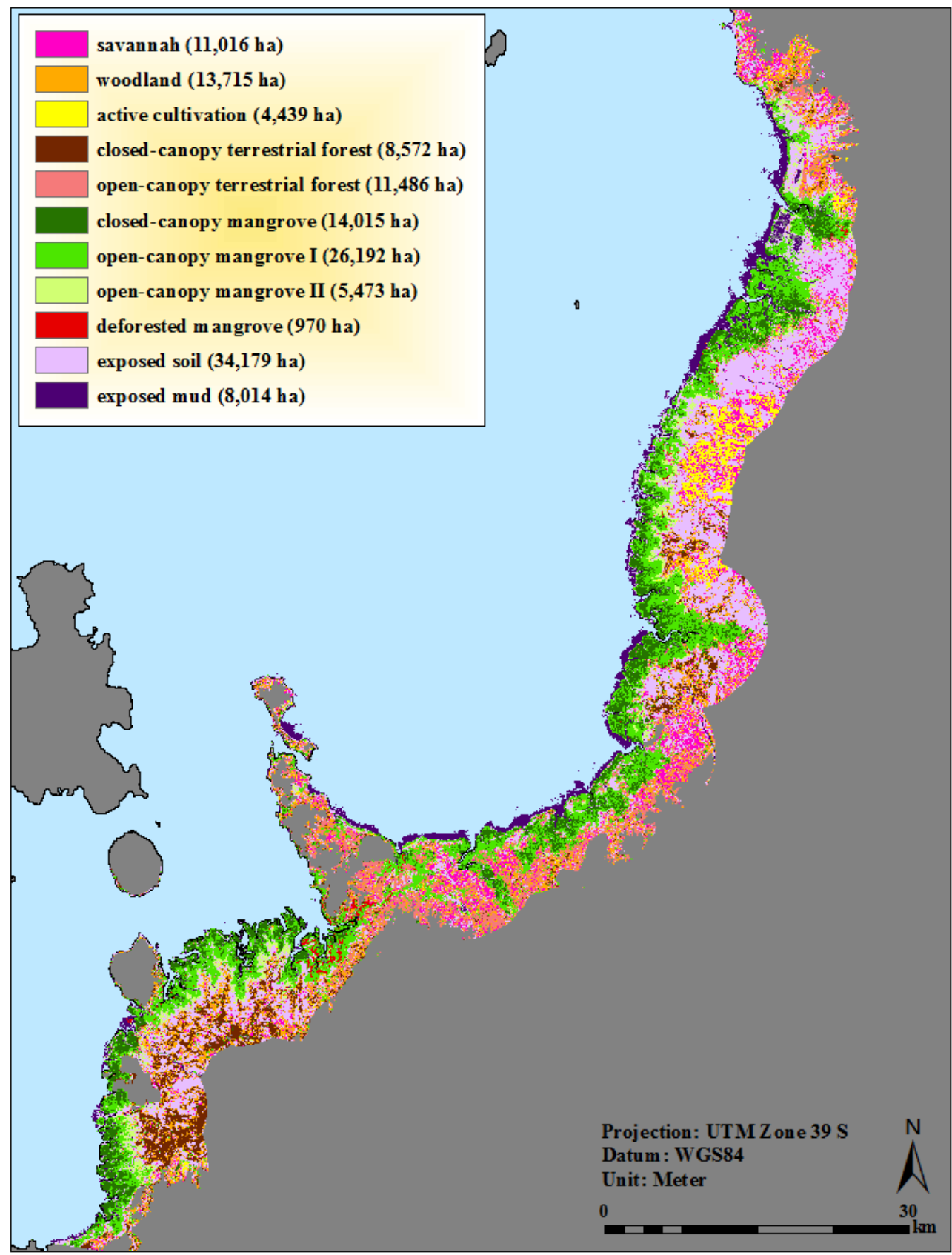


Table 3. Confusion matrix for maximum likelihood classification of GLS 2010 Landsat data.

\begin{tabular}{ccccccccccccccc}
\hline & $\mathbf{1}$ & $\mathbf{2}$ & $\mathbf{3}$ & $\mathbf{4}$ & $\mathbf{5}$ & $\mathbf{6}$ & $\mathbf{7}$ & $\mathbf{8}$ & $\mathbf{9}$ & $\mathbf{1 0}$ & $\mathbf{1 1}$ & Total & User's (\%) & Commission (\%) \\
\hline Savannah (1) & 54 & 3 & 0 & 0 & 0 & 0 & 0 & 0 & 0 & 1 & 0 & 58 & 93 & 7 \\
Woodland (2) & 0 & 39 & 0 & 0 & 0 & 0 & 0 & 0 & 0 & 0 & 0 & 39 & 100 & 0 \\
Active crops (3) & 0 & 0 & 51 & 0 & 0 & 0 & 0 & 0 & 0 & 0 & 0 & 51 & 100 & 0 \\
Closed-canopy terrestrial forest (4) & 0 & 0 & 0 & 54 & 0 & 0 & 0 & 0 & 0 & 0 & 0 & 54 & 100 & 0 \\
Open-canopy terrestrial forest (5) & 0 & 4 & 0 & 0 & 54 & 0 & 0 & 0 & 0 & 0 & 0 & 58 & 93 & 7 \\
Closed-canopy mangrove (6) & 0 & 0 & 0 & 0 & 0 & 79 & 9 & 0 & 0 & 0 & 0 & 88 & 90 & 10 \\
Open-canopy mangrove I (7) & 0 & 0 & 0 & 0 & 0 & 11 & 72 & 0 & 2 & 0 & 0 & 85 & 85 & 15 \\
Open-canopy mangrove II (8) & 0 & 0 & 0 & 0 & 0 & 0 & 0 & 52 & 0 & 0 & 0 & 52 & 100 & 0 \\
Deforested mangrove (9) & 0 & 0 & 0 & 0 & 0 & 0 & 0 & 0 & 60 & 0 & 0 & 60 & 100 & 0 \\
Exposed soil (10) & 0 & 8 & 3 & 0 & 0 & 0 & 0 & 2 & 1 & 53 & 0 & 67 & 79 & 21 \\
Exposed mud (11) & 0 & 0 & 0 & 0 & 0 & 0 & 0 & 0 & 0 & 0 & 54 & 54 & 100 & 0 \\
Total & 54 & 54 & 54 & 54 & 54 & 90 & 81 & 54 & 63 & 54 & 54 & 666 & & 93.4
\end{tabular}


A comparison with the 24,669 ha of mangrove coverage provided by the 2010 USGS classification highlights the shortcomings of localized applications for this national-level dataset (Figure 5). While USGS distribution maps provide unprecedented detail and accuracy, they are limited to one mangrove class and provide no information on surrounding land-cover categories. In addition, while comprehensively representing taller, intact, mature stands, the USGS map depicts 21,011 ha less mangroves than our results, underrepresenting the naturally lower stature and more open stands and highly degraded areas and completely omitting most scrub ecosystems. This underrepresentation can lead to exaggerated loss estimates, as field observations confirm that many of the deforested areas identified through analyzing the time series of USGS mangrove maps are occupied by naturally lower stature and more open areas and highly degraded stands.

\subsection{Carbon Plot Locations and Ecological Characteristics of Mapped Mangrove Classes}

Figure 6 shows the location of $\mathrm{C}$ plots established within mangrove strata. Plot-level measurements enabled the summarization of the forest characteristics associated with each mapped mangrove class, including sub-class type ecological summaries (Table 4). Open-canopy II plots were comprised of sparse and stunted low stature Avicennia marina with extremely open (i.e., <30\%) canopies. Open-canopy I plots were primarily represented by moderately-dense stands of medium stature Ceriops tagal and Rhizophora mucronata with relatively open canopies. Closed-canopy plots were typified by high stature stands dominated by Rhizophora mucronata and exhibiting variable density, but well-formed canopies. Exceptions to the typical forest characteristics of mapped classes include stands dominated by naturally very open and/or highly degraded high stature trees, which were sometimes mapped as open-canopy I. In addition, extremely dense moderate stature stands sometimes appear as closed-canopy in the imagery.

At the scale of analysis (i.e., ha-level), there is negligible difference in the spectral appearance of areas of relatively open-canopy medium stature trees and those comprised of tall trees that were naturally open or had been heavily harvested and/or naturally degraded. While mangrove conversion (i.e., deforestation) is reliable for mapping using established methods and readily available Landsat data, accurately detecting and tracking subtler modification (i.e., degradation) remains a vexing challenge. Whether naturally-induced (e.g., cyclone damage) or resulting from anthropogenic exploitation, sub-pixel change in forest appearance is difficult to accurately measure using moderate spatial resolution remotely sensed data (e.g., Landsat). This challenge highlights the need to research applying methods developed for mapping selective logging in terrestrial forests [126] to assessing mangrove degradation. In addition, the synergistic combination of Landsat imagery with complimentary remotely sensed datasets, including finer spatial resolution optical imagery and the structural information offered by light detection and ranging (LiDAR), needs to be explored further, bearing in mind that such datasets can be prohibitively expensive and rarely available in wall-to-wall coverage for dates and locations of interest [11]. While further work is needed to allow for partitioning existing classes based on their level of degradation, confidently differentiating between natural and anthropogenic degradation will remain problematic, even if separable from naturally intact stands. Bearing in mind the mangrove class and methodological limitations, observations in forest plots confirmed that our broad canopy-cover classes are ecologically rational and associable with 
statistically distinct $\mathrm{C}$ stocks. While the remote sensing of canopy closure is a major topic of research for terrestrial forests and previous studies have shown that extremely closed-canopies are indicative of forest stands comprised of higher stature trees (e.g., [127]), our results contribute to what Heumann [68] summarizes as a comparative dearth of mangrove canopy-closure studies.

Figure 5. Comparison between GLS 2010 Landsat classification results (top left) and single-class USGS 2010 mangrove coverage (top right) for a sub-set of the area of interest (AOI). A Landsat Enhanced Thematic Mapper (ETM+) color composite, where band 3 is blue, band 5 is green and band 4 is red, is shown for context (bottom left).
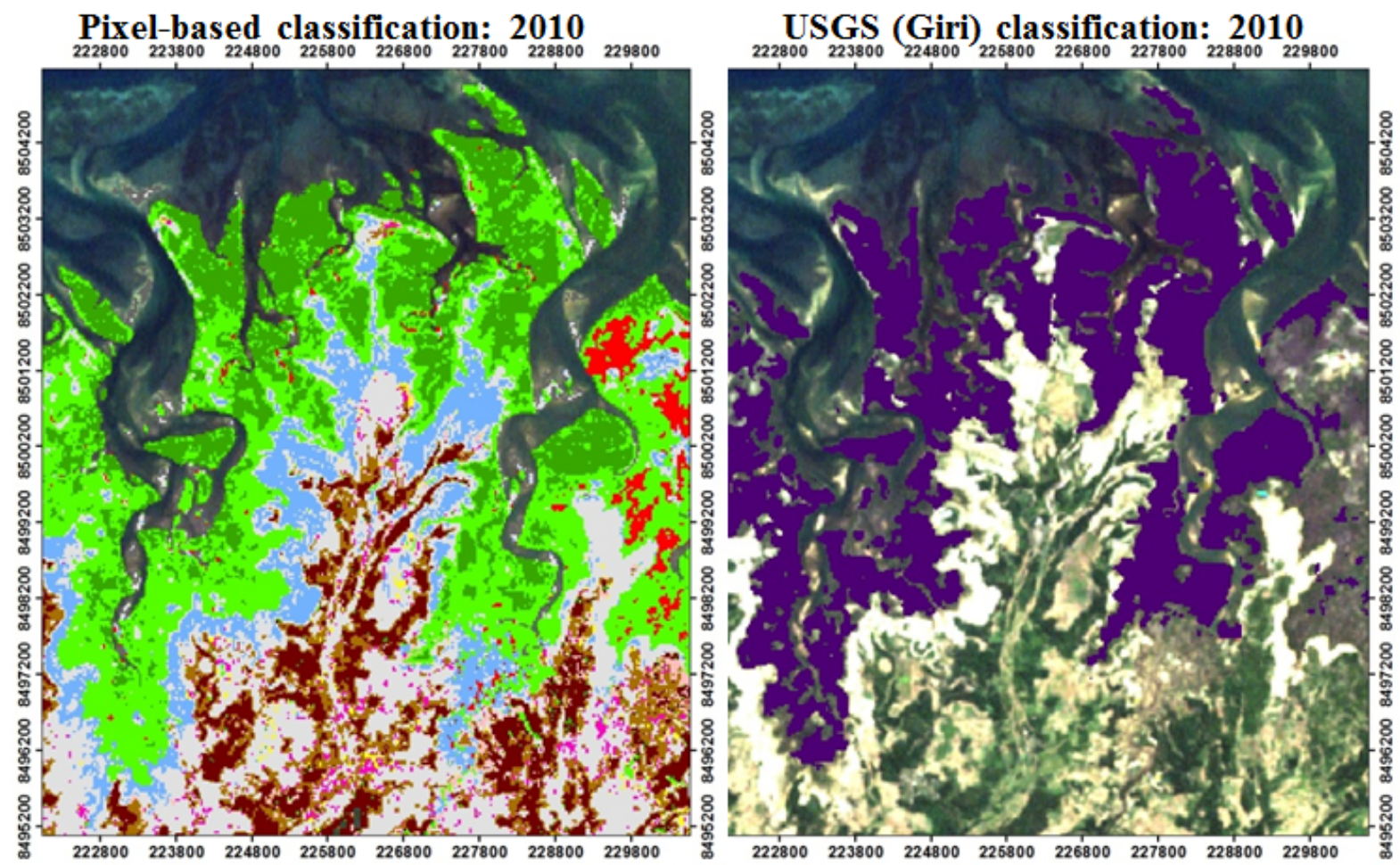

Landsat ETM+
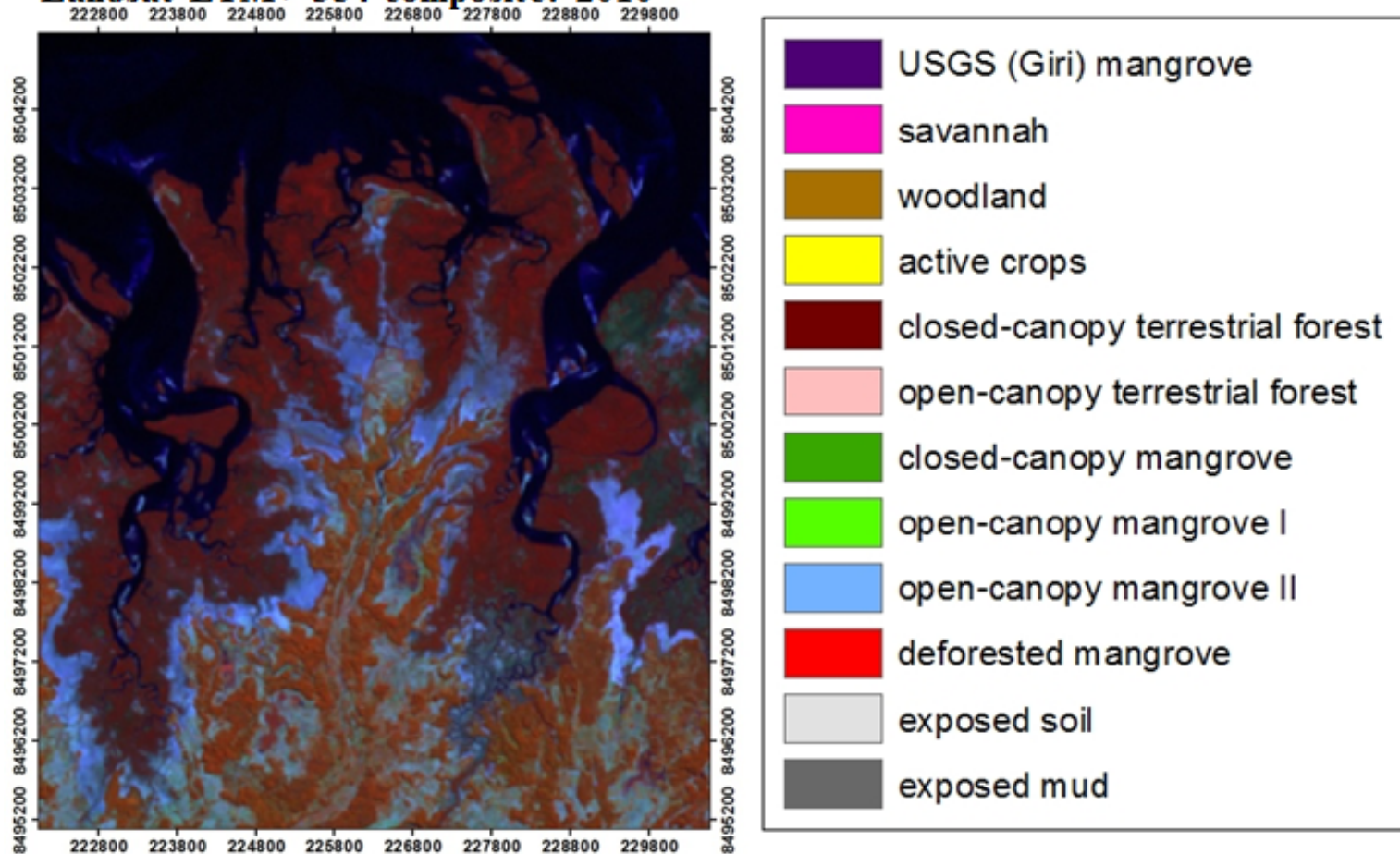

$\begin{array}{llllllll}222800 & 223800 & 224800 & 225800 & 226800 & 227800 & 228800 & 229800\end{array}$ 
Figure 6. The location of $\mathrm{C}$ plots within classified mangrove strata.

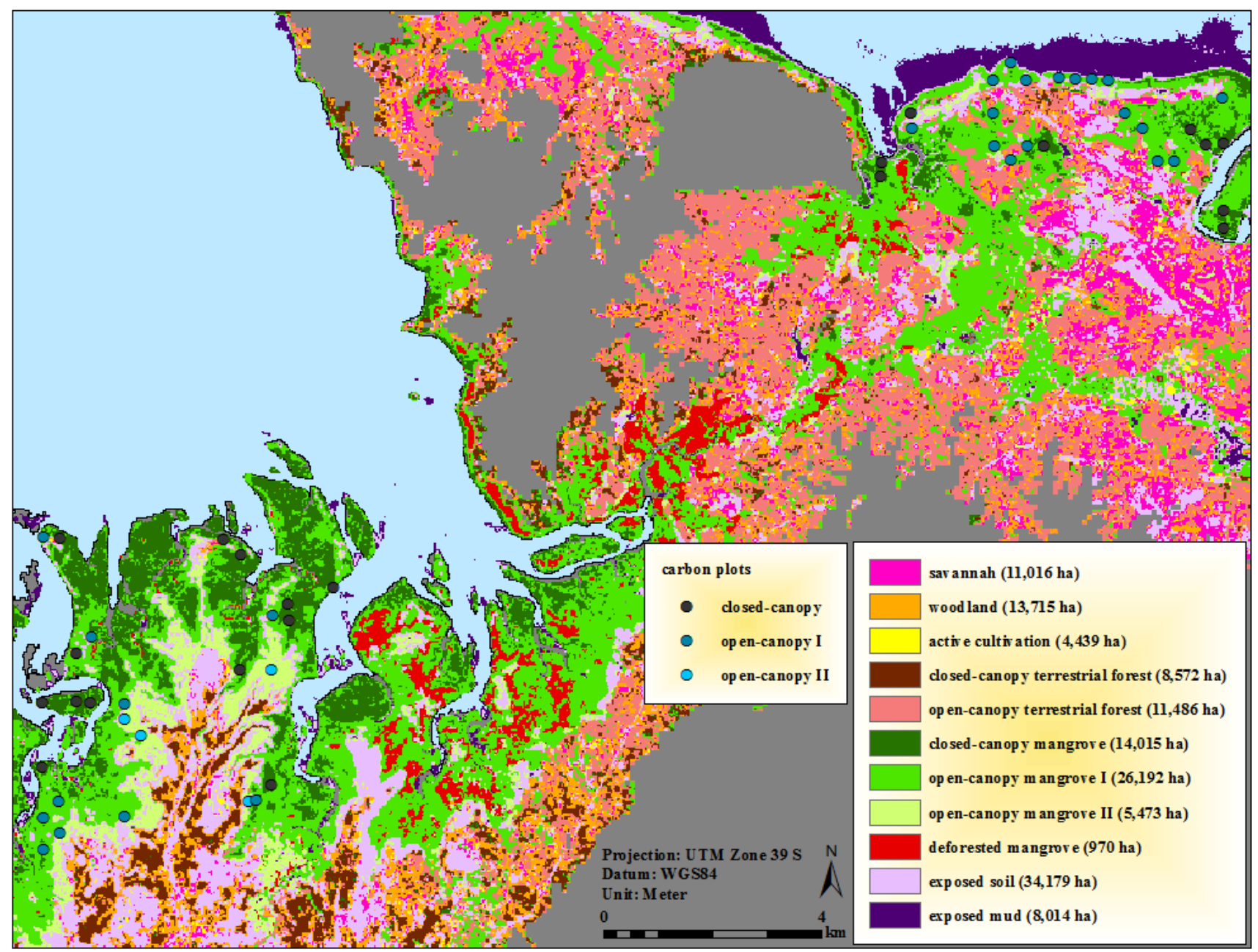

\subsection{Carbon Stocks of Mapped Mangrove Classes}

Plot-level biomass estimates were converted to C stocks and scaled to the hectare-level (Figure 7, Tables 5 and 6). Closed-canopy mangrove trees had by far the highest vegetation and total biomass values. On average, closed-canopy vegetation (i.e., live and dead, above- (i.e., tree) and below-ground (i.e., roots)) had an estimated $\mathrm{C}$ value of $146.8 \mathrm{Mg} /$ ha $( \pm 10.2$ (i.e., 1 standard error $))(n=25)$. The average SOC value for closed-canopy mangroves was $446.2( \pm 36.9)(n=22)$. Open-canopy mangrove I had average $\mathrm{C}$ values of $42.9 \mathrm{Mg} / \mathrm{ha}( \pm 5.9)$ (vegetation: $n=28)$ and $324.4 \mathrm{Mg} / \mathrm{ha}( \pm 36.5)$ (SOC: $n=24$ ). Open-canopy II values were lower than other classes for vegetation (i.e., $20.9 \mathrm{Mg} / \mathrm{ha}$ $( \pm 4.6))(n=4)$, but SOC values were the highest of any type (i.e., $517.1( \pm 76))(n=4)$. The high open-canopy II SOC values are most likely attributable to the smaller sample size (i.e., $n=4)$ and additional plots are required in this mangrove strata to more robustly estimate $\mathrm{C}$. 
Table 4. Class sub-type, species (spp) dominance, average height in meters ( $\mathrm{m})$ ( \pm 1 standard deviation (SD)), average trees per hectare (ha) $( \pm 1$ SD) and average diameter (d) in centimetres $(\mathrm{cm})( \pm 1$ SD). Trees/ha (i.e., density) calculated for intact plots. $\mathrm{N}$ represents plots per class sub-type.

\begin{tabular}{|c|c|c|c|c|c|}
\hline Class & Sub-type & Spp dominance & Height (m) ( \pm 1 SD) & $\begin{array}{l}\text { Trees/ha } \\
\text { ( } \pm 1 \text { SD) }\end{array}$ & $\begin{array}{l}\text { d (cm) } \\
( \pm 1 \mathrm{SD})\end{array}$ \\
\hline \multirow{6}{*}{ Closed-canopy $(n=24)$} & intact, tall, mature stands & Avicennia marina & $8.6(n=1)$ & $1250(n=1)$ & $14.9(n=1)$ \\
\hline & intact, tall, mature stands & Ceriops tagal & $7.3( \pm 1.2)(n=3)$ & $2625( \pm 318)(n=2)$ & $10.1( \pm 0.5)(n=3)$ \\
\hline & intact, tall, mature stands & Rhizophora mucronata & $7( \pm 1.3)(n=14)$ & $4719( \pm 1133)(n=12)$ & $10.1( \pm 3)(n=14)$ \\
\hline & intact, tall, mature stands & Sonneratia alba & $5.6(n=1)$ & $5300(n=1)$ & $10.6(n=1)$ \\
\hline & very dense medium-tall stands & Rhizophora mucronata & $4.8( \pm 0.1)(n=2)$ & $5600( \pm 1838)(n=2)$ & $7.8( \pm 1.1)(n=2)$ \\
\hline & intact, tall, mature stands & mixed & $6.7( \pm 1.6)(n=2)$ & $1825( \pm 248)(n=2)$ & $11.3( \pm 2.5)(n=2)$ \\
\hline \multirow{5}{*}{ Open-canopy I $(n=28)$} & medium stands & Ceriops tagal & $4.6( \pm 0.8)(n=7)$ & $3300( \pm 849)(n=2)$ & $7.5( \pm 1.6)(n=7)$ \\
\hline & medium stands & Rhizophora mucronata & $4.2( \pm 0.6)(n=6)$ & $2160( \pm 498)(n=5)$ & $7.3( \pm 1.3)(n=6)$ \\
\hline & naturally open/very degraded tall & variable & $5.7( \pm 0.3)(n=4)$ & $1525( \pm 35)(n=2)$ & $10.1( \pm 1.2)(n=4)$ \\
\hline & very dense short stands & Ceriops tagal & $2.5( \pm 0.3)(n=9)$ & $2780( \pm 750)(n=5)$ & $5.1( \pm 0.9)(n=9)$ \\
\hline & medium stands & mixed & $4.8( \pm 0.1)(n=2)$ & $1800( \pm 141)(n=2)$ & $9.5( \pm 2)(n=2)$ \\
\hline Open-canopy II $(n=4)$ & stunted, scrub ecosystems & Avicennia marina & $1.7( \pm 0.5)(n=4)$ & $1306( \pm 554)(n=4)$ & $4.6( \pm 0.2)(n=4)$ \\
\hline
\end{tabular}


Figure 7. Estimated average ( \pm 1 standard error) above- and below-ground carbon stocks (ton/hectare (ha)) for mapped mangrove classes in Ambanja and Ambaro bays. Below-ground soil strata depths are in centimeters $(\mathrm{cm})$.

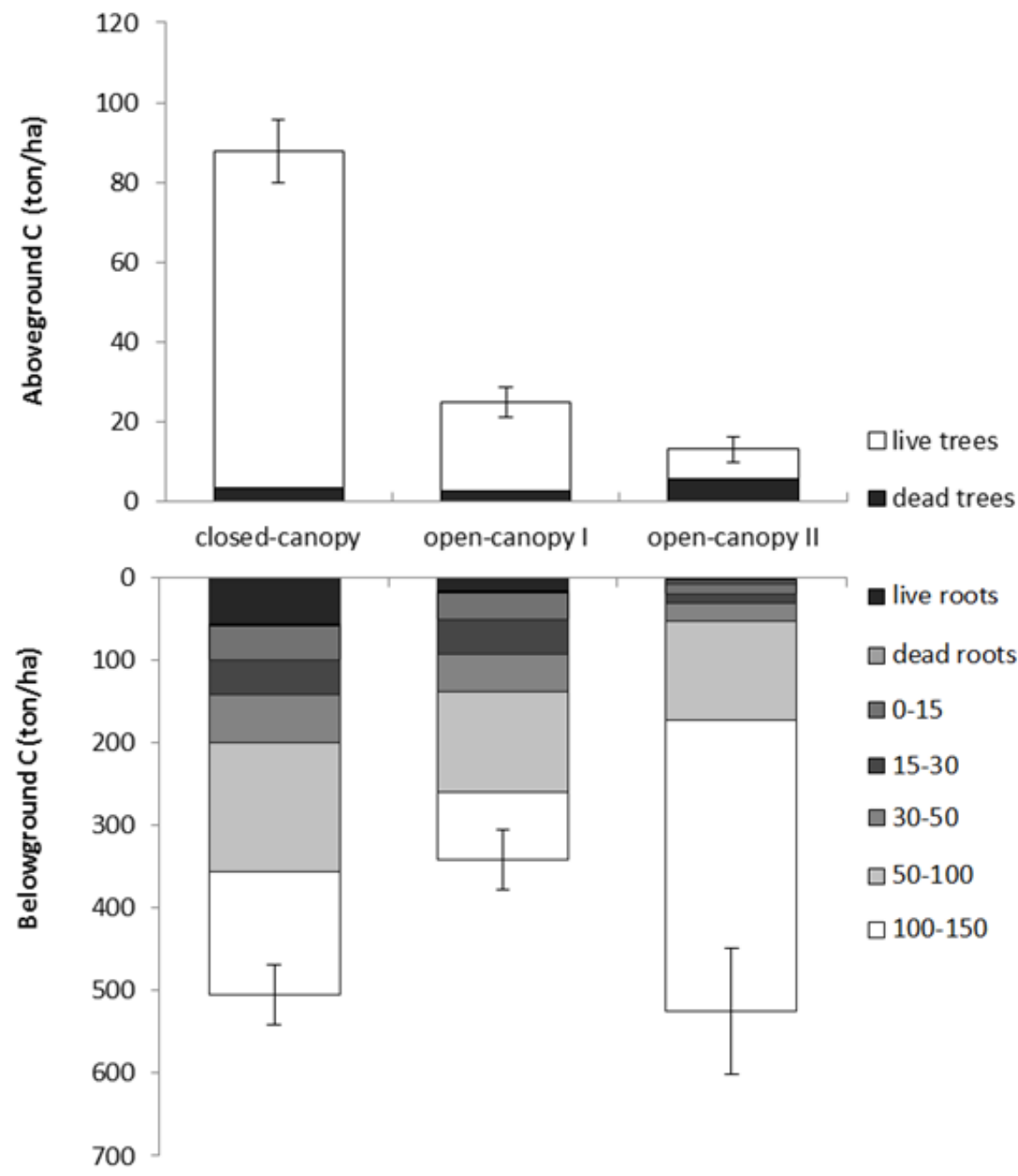

Table 5. Average hectare (ha)-level carbon ( $\mathrm{Mg} / \mathrm{ha})$ estimates $( \pm 1$ standard error) for mangrove vegetation (dead and live, above and roots), soil organic carbon (SOC) and total carbon. Estimates are partitioned by strata. $\mathrm{N}$ represents the number of plots per class type, with two $n$ values corresponding to trees and soil, respectively.

\begin{tabular}{llll}
\hline Class & Vegetation carbon & Soil organic carbon & Total carbon \\
\hline Closed-canopy $(n=23 ; 22)$ & $146.8(10.2)$ & $446.2(36.9)$ & $593(39)$ \\
Open-canopy I $(n=28 ; 24)$ & $42.9(5.8)$ & $324.3(36.5)$ & $367.2(37.3)$ \\
Open-canopy II $(n=4 ; 4)$ & $20.8(4.6)$ & $517.1(76)$ & $537.9(75.2)$ \\
\hline
\end{tabular}


Table 6. Average hectare (ha)-level carbon (\%), bulk density $\left(\mathrm{g} / \mathrm{cm}^{3}\right)$ and carbon mass ( $\mathrm{Mg} / \mathrm{ha}$ ) estimates \pm 1 standard error (in brackets). Estimates are partitioned by mapped mangrove class and soil depth strata. $\mathrm{N}$ corresponds with the number of plots per class type.

\begin{tabular}{lcccccrr}
\hline Class & $\begin{array}{c}\text { Sample depth } \\
(\mathbf{c m})\end{array}$ & \multicolumn{2}{c}{$\begin{array}{c}\text { Carbon } \\
(\mathbf{\%})\end{array}$} & \multicolumn{2}{c}{$\begin{array}{c}\text { Bulk density } \\
\left(\mathbf{g} / \mathbf{c m}^{3}\right)\end{array}$} & \multicolumn{2}{c}{$\begin{array}{c}\text { Carbon mass } \\
(\mathbf{M g} / \mathbf{h a})\end{array}$} \\
\hline Closed-canopy $(n=22)$ & $0-15$ & 4.8 & $(0.9)$ & 0.77 & $(0.08)$ & 41.1 & $(3.5)$ \\
& $15-30$ & 4.1 & $(0.4)$ & 0.73 & $(0.08)$ & 41.3 & $(3.7)$ \\
& $30-50$ & 4.1 & $(0.3)$ & 0.73 & $(0.06)$ & 58.4 & $(3.9)$ \\
& $50-100$ & 4.2 & $(0.4)$ & 0.72 & $(0.06)$ & 155.6 & $(14.9)$ \\
& $100-150$ & 3.9 & $(0.5)$ & 0.70 & $(0.09)$ & 149.8 & $(17.4)$ \\
& Total & & & & & 446.2 & $(36.9)$ \\
Open-canopy I $(n=24)$ & $0-15$ & 3.4 & $(2.9)$ & 0.78 & $(0.08)$ & 32.5 & $(3.8)$ \\
& $15-30$ & 4.4 & $(3.6)$ & 0.72 & $(0.07)$ & 43.1 & $(5.3)$ \\
& $30-50$ & 3.2 & $(2.6)$ & 0.75 & $(0.07)$ & 45.2 & $(5.6)$ \\
& $50-100$ & 3.2 & $(2.6)$ & 0.60 & $(0.08)$ & 120.7 & $(16.9)$ \\
& $100-150$ & 1.9 & $(2.2)$ & 0.52 & $(0.10)$ & 82.9 & $(18.3)$ \\
& Total & & & & & 324.3 & $(36.5)$ \\
Open-canopy II $(n=4)$ & $0-15$ & 0.6 & $(0.1)$ & 1.39 & $(0.04)$ & 12.1 & $(0.7)$ \\
& $15-30$ & 0.6 & $(0.3)$ & 1.28 & $(0.05)$ & 10.6 & $(2.6)$ \\
& $30-50$ & 0.8 & $(0.6)$ & 1.35 & $(0.06)$ & 22.5 & $(7.4)$ \\
& $50-100$ & 2.2 & $(1.2)$ & 1.10 & $(0.03)$ & 120.0 & $(28.9)$ \\
& $100-150$ & 6.1 & $(2.4)$ & 1.18 & $(0.08)$ & 351.9 & $(58.1)$ \\
& Total & & & & & 517.1 & $(76.0)$ \\
\hline
\end{tabular}

A comparison of our results with existing published $\mathrm{C}$ stocks for mangroves indicates that our values are comparatively low. For example, mangroves sampled throughout the Indo-Pacific averaged $1023 \mathrm{Mg} / \mathrm{ha}, 49 \%-98 \%$ of which were directly associated with organic-rich soils [15]. In western Micronesia, specifically Yap state and the Republic of Palau, mangrove $\mathrm{C}$ storage ranged from 479 (seaward) to 1385 (landward) $\mathrm{Mg} /$ ha, with $70 \%$ of storage in soils [27]. While the $\mathrm{C}$ stocks reported here are not nearly as high as those reported in the Indo-Pacific and western Micronesia, Madagascar's mangroves are typically of a lower stature, and our soil samples were only collected to $1.5 \mathrm{~m}$. In addition, our soil samples were analyzed using the Walkley-Black method, which is known to under-represent SOC [114-118]. However, as there are few professional laboratories in Madagascar that analyze soil, and all employ only this approach, we chose the LRI, given the expense of sending samples abroad to be analyzed and the critical need to build local scientific capacity. Future research requires setting up the equipment required to conduct more accurate soil analysis in Madagascar. Acknowledging the shortcomings of the Walkley-Black, the results provide preliminary conservative SOC estimates, which, compared to other terrestrial forest types (e.g., boreal, temperate, tropical upland), still support a growing body of evidence that mangroves are amongst the most carbon-dense forests in the tropics, with similar above- and larger below-ground stocks than terrestrial systems [15,27-30,32-34,38] (Figure 8). For above-ground carbon, our results further support that closed-canopies are indicative of higher stature trees, which typically sequester significantly larger amounts of $\mathrm{C}$ than more open stands [127]. 
Figure 8. Estimated carbon stocks for Madagascar ( \pm 1 standard error) compared with published carbon stocks for different forest types. Carbon stocks for non-mangrove forest types are taken from [15]. Soil organic carbon comparisons are made to a depth of $1 \mathrm{~m}$.

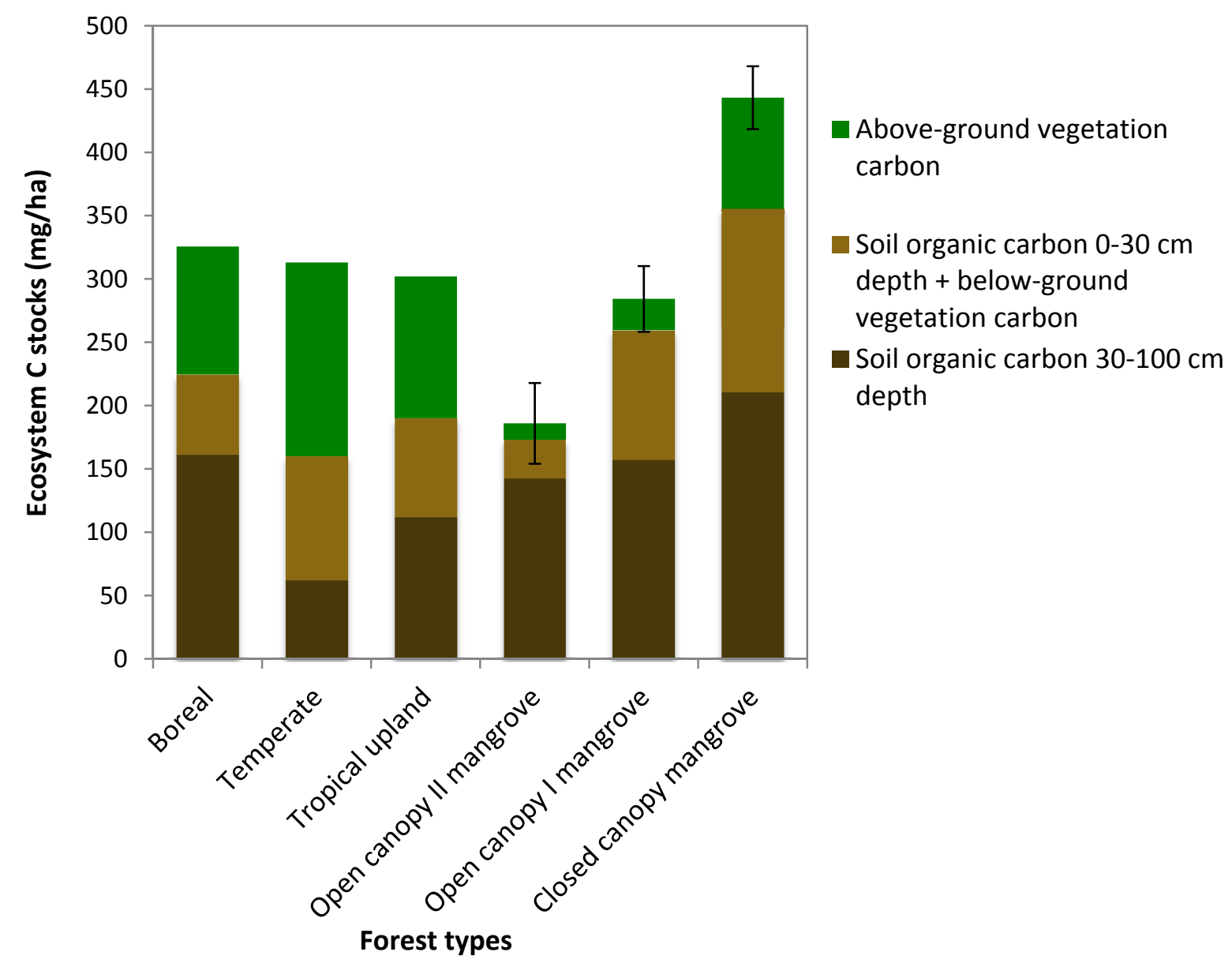

\section{Conclusions}

Owing to a complex and ever-dynamic scene composition, mangrove mapping is one of the most demanding tasks in remote sensing [11]. While our mapping results are not without their acknowledged shortcomings, they allow for ecologically meaningful stratification associable with distinct $\mathrm{C}$ stocks. Our simple, yet effective and replicable classification of moderate spatial resolution remotely sensed data provides improved detail and accuracy over existing mangrove coverage and unprecedented information for surrounding land-cover categories. Our initial C stock estimates are also not without their limitations, most notably the Walkley-Black-based estimation of SOC; however, they are conservative and can be improved over time. To improve these initial SOC estimates, existing samples should be reanalyzed once the equipment necessary to facilitate more robust analysis becomes available in-country. In addition, more plots should be established within the open-canopy II strata. Current above- and below-ground tree-related $\mathrm{C}$ estimates could also be improved through destructive sampling and developing Madagascar-specific allometric equations.

Although preliminary, our results support ongoing initiatives investigating the feasibility of and working towards implementing mangrove carbon financing projects (e.g., Reducing Emissions from 
Deforestation and forest Degradation (REDD)+) and other payments for ecosystem services (PES). In particular, the generation of carbon credits through the conservation, restoration and lower-impact use of mangroves could make vital contributions to alleviating poverty and safeguarding biodiversity in coastal Madagascar. Throughout the tropics, hundreds of REDD+ and PES projects have been initiated, yet in few countries are there projects focusing specifically on mangroves (see [128]).

Our mapping results, supported by extensive field observations, confirm that as of 2010, anthropogenic activities, fueled by a diverse and complex range of drivers, including a lack of governance and increasing population, had driven substantial deforestation (i.e., 970 ha) in Madagascar's second largest mangrove ecosystem. Ongoing research supports this trend nation-wide, and while natural processes, such as forest succession, linked with sedimentological processes and cyclone impacts, are important causes of change, Madagascar's mangroves are facing increasing anthropogenic impact. While in certain places, such as the AOI of this study, wide-spread deforestation is apparent, the likelihood and long-term outcome of natural or assisted regeneration remains uncertain. However, continued degradation and deforestation could compromise, if not discontinue, many of the ecosystem services offered by intact mangrove ecosystems. The continued modification and conversion of mangrove habitat, if left to proceed unimpeded, could also continue to influence global climate through increased greenhouse gas emissions and increase the risk for ripple effects that can negatively influence surrounding and closely linked marine and terrestrial ecosystems. The first step towards mitigation is quantifying the extent of and contextualizing the reasons for and consequences of loss. Here, we have advanced this agenda for Madagascar by presenting the first localized land-cover map for Ambanja and Ambaro bays and the country's first above- and below-ground $\mathrm{C}$ stocks.

\section{Acknowledgments}

This research was funded by grants from the Western Indian Ocean Marine Science Association and the John D. and Catherine T. MacArthur Foundation. Thanks to Joseph Langat (Kenya Marine and Fisheries Research Institute) for assistance with adapting field techniques and undertaking carbon stock measurements. Additional thanks to Zo Andriamahenina and Rado Rakotomanana (Blue Ventures), Pierre-Francois Roy (Institut Catholique des Arts et Métiers), and Holy Andriamitantsoa and Tina Haingonirina (Institut Halieutique et des Sciences Marines) for assistance with data collection. Extensive gratitude is owed to numerous local guides and field assistants from the coastal Malagasy communities of Port St Louis, Ampampamena, Antetezambato and Ambolikapiki. Thanks also to Aude Carro and Kate England (Blue Ventures) for socio-economic context and to Leah Glass and Samir Gandhi (Blue Ventures) and Mitchell Vartanian and Anna Yuill (UBC) for assistance with manuscript preparation. Additional thanks to J. Boone Kauffman (Oregon State University) for technical advice, particularly assistance with selecting allometric equations, and to two extremely helpful anonymous reviewers.

\section{Conflicts of Interest}

The authors declare no conflict of interest. 


\section{References}

1. Lugo, A.E.; Snedaker, S.C. The ecology of mangroves. Annu. Rev. Ecol. Syst. 1974, 5, 39-64.

2. Blasco, F.; Bellan, M.F.; Chaudhury, M.U. Estimating the extent of floods in bangladesh-Using SPOT data. Remote Sens. Environ. 1992, 39, 167-178.

3. Marshall, N. Mangrove conservation in relation to overall environmental considerations. Hydrobiologia 1994, 285, 303-309.

4. Alongi, D.M. Present state and future of world's mangrove forest. Environ. Conserv. 2002, 29, 331-349.

5. Dahdouh-Guebas, F.; Jayatissa, L.P.; di Nitto, D.; Bosire, J.O.; Lo Seen, D.; Koedam, N. How effective were mangroves as a defence against the recent tsunami? Curr. Biol. 2005, 15, R443-R447.

6. Barbier, E.B. Natural barriers to natural disasters: Replanting mangroves after tsunami. Front. Ecol. Environ. 2006, 4, 124-131.

7. Food and Agricultural Organization (FAO). The World's Mangroves 1980-2005; FAO Forestry Paper 153; FAO: Rome, Italy, 2007.

8. Alongi, D.M. Mangrove forests: Resilience, protection from tsunamis, and responses to global climate change. Estuar. Coast. Shelf Sci. 2008, 76, 1-13.

9. Nagelkerken, I.; Blaber, S.J.; Bouillon, S.; Green, P.; Haywood, M.; Kirton, L.G.; Meynecke, J.-O.; Pawlik, J.; Penrose, H.M.; Sasekumar, A.; et al. The habit function of mangroves for terrestrial and marine fauna: A review. Aquat. Bot. 2008, 89, 155-185.

10. Alongi, D.M. Carbon payments for mangrove conservation: Ecosystem constraints and uncertainties of sequestration potential. Environ. Sci. Policy 2011, 14, 462-470.

11. Kuezner, C.; Bluemel, A.; Gebhardt, S.; Quoc, T.V.; Dech, S. Remote sensing of mangrove ecosystems: A review. Remote Sens. 2011, 3, 878-928.

12. Primavera, J.H. Socio-economic impacts of shrimp culture. Aquac. Res. 1997, 28, 815-827.

13. Kathiresan, K.; Bingham, B. Biology of mangroves and mangrove ecosystems. Adv. Mar. Biol. 2001, 40, 81-251.

14. Mumby, P.J.; Edwards, A.J.; Arias-Gonzáles, E.; Lindeman, K.C.; Blackwell, P.G.; Gall, A.; Gorczynska, M.I.; Harborne, A.R.; Pescod, C.L.; Renken, H.; et al. Mangrove enhance the biomass of coral reef fish communities in the Caribbean. Nature 2004, 427, 533-536.

15. Donato, D.C.; Kauffman, J.B.; Murdiyarso, D.; Kumianto, S.; Stidham, M.; Kanninen, M. Mangroves among the most carbon-rich forests in the tropics. Nat. Geosci. 2011, 4, 293-297.

16. Pendleton, L.; Donato, D.C.; Murray, B.C.; Crooks, S.; Jenkins, W.A.; Sifleet, S.; Craft, C.; Fourqurean, J.W.; Kauffman, J.B.; Marba, N.; et al. Estimating global "blue carbon" emissions from conversion and degradation of vegetated coastal ecosystems. PLoS One 2012, 7, e43542.

17. Twilley, R.R.; Chen, R.H.; Hargis, T. Carbon sinks in mangroves and their implications to carbon budget of tropical coastal ecosystems. Water Air Soil Pollut. 1992, 64, 265-288.

18. Kirui, K.B.; Karachi, M.; Kairo, J.G. Allometric equations for estimating aboveground biomass of Rhizophora mucronata at Gazi bay Kenya. West. Indian. Ocean J. Mar. Sci. 2006, 5, 27-34.

19. Komiyama, A.; Ong, J.E.; Poungparn, S. Allometry, biomass, and productivity of mangrove forests: A review. Aquat. Bot. 2008, 89, 128-137. 
20. Alongi, D.M. The Energetics of Mangrove Forests; Springer Science and Business Media BV: New York, NY, USA, 2009.

21. Kairo, J.G.; Bosire, J.; Langat, J.; Kirui, B.; Koedam, N. Allometry and biomass distribution in replanted mangrove plantations at Gazi Bay, Kenya. Aquat. Conserv. 2009, 19, S63-S69.

22. Kauffman, J.B.; Cole, T.G. Micronesian mangrove forest structure and tree responses to a severe typhoon. Wetlands 2010, 30, 1077-1084.

23. Camacho, L.D.; Gevana, D.T.; Carandang, A.P.; Sofronio, C.C.; Combalicer, E.A.; Rebugio, L.L.; Youn, Y.-C. Tree biomass and carbon stock of a community-managed mangrove forest in Bohol, Phillipines. For. Sci. Technol. 2011, 7, 161-167.

24. Mitra, A.; Sengupta, K.; Banerjee, K. Standing biomass and carbon storage of above-ground structures in dominant mangrove trees in the Sundarbans. For. Ecol. Manag. 2011, 261, 1325-1335.

25. Abino, A.C.; Castillo, J.A.A.; Lee, Y.J. Assessment of species diversity, biomass and carbon sequestration potential of a natural mangrove stand in Samar, the Philippines. For. Sci. Technol. 2013, doi:10.1080/21580103.2013.814593.

26. Hutchison, J.; Manica, A.; Swetnam, R.; Balmford, A.; Spalding, M. Predicting global patterns in mangrove forest biomass. Conserv. Lett. 2013, doi:10.1111/conl.12060.

27. Kauffman, J.B.; Heider, C.; Cole, T.G.; Dwire, K.A.; Donato, D.C. Ecosystem carbon stocks of Micronesian mangrove forests. Wetlands 2011, 31, 343-352.

28. Ray, R.; Ganguly, D.; Chowdhury, C.; Dey, M.; Das, S.; Dutta, M.K.; Mandal, S.K.; Majumder, N.; De, T.K.; Mukhopadhyay, S.K.; et al. Carbon sequestration and annual increase of carbon stock in a mangrove forest. Atmos. Environ. 2011, 45, 5016-5024.

29. Chen, L.; Zeng, X.; Tam, N.F.Y.; Lu, W.; Luo, Z.; Du, X.; Wang, J. Comparing carbon sequestration and stand structure of monoculture and mixed mangrove plantations of Sonneratia caseolaris and S. apetala in Southern China. For. Ecol. Manag. 2012, 284, 222-229.

30. Donato, D.C.; Kauffman, J.B.; Mackenzie, R.A.; Ainsworth, A.; Pfleeger, A.Z. Whole-island carbon stocks in the tropical Pacific: Implications for mangrove conservation and upland restoration. J. Environ. Manag. 2012, 97, 89-96.

31. Matsui, N.; Morimune, K.; Meepol, W.; Chukwamdee, J. Ten year evaluation of carbon stock in mangrove plantation reforested from an abandoned shrimp pond. Forests 2012, 3, 431-444.

32. Adame, M.F.; Kauffman, J.B.; Medina, I.; Gamboa, J.N.; Torres, O.; Caamal, J.P.; Reza, M.; Herrera-Silveira, J.A. Carbon stocks of tropical coastal wetlands within the Karstic landscape of the Mexican Caribbean. PLoS One 2013, 8, e56569.

33. Wang, G.; Dongsheng, G.; Peart, M.R.; Chen, Y.; Peng, Y. Ecosystem carbon stocks of mangrove forest in Yingluo Bay, Guangdon Province of South China. For. Ecol. Manag. 2013, 310, 539-546.

34. Kauffman, J.B.; Heider, C.; Norfolk, J.; Payton, F. Carbon stocks of intact mangroves and carbon emissions arising from their conversion in the Dominican Republic. Ecol. Appl. in press, doi:10.1890/13-0640.1

35. Golley, F.; Odum, H.T.; Wilson, R.F. The structure and metabolism of a Puerto Rican red mangrove forest in May. Ecology 1962, 43, 9-19.

36. Eong, O.J. Mangroves_A carbon source and sink. Chemosphere 1993, 27, 1097-1107. 
37. Matsui, N. Estimated stocks of organic carbon in mangrove roots and sediments in Hinchinbrook Channel, Australia. Mangroves Salt Marshes 1998, 2, 199-204.

38. Fujimoto, K.; Imaya, A.; Tabuchi, R.; Kuramoto, S.; Utsugi, H.; Murofushi, T. Belowground C storage of Micronesian mangrove forests. Ecol. Res. 1999, 14, 409-413.

39. Kauffman, J.B.; Donato, D.C. Protocols for the Measurement, Monitoring and Reporting of Structure, Biomass and Carbon Stocks in Mangrove Forests. Working Paper 86; CIFOR: Bogor, Indonesia, 2012.

40. Giri, C.; Ochieng, E.; Tieszen, L.L.; Zhu, Z.; Singh, A.; Loveland, T.; Masek, J.; Duke, N. Status and distribution of mangrove forests of the world using earth observation satellite data. Glob. Ecol. Biogeogr. 2011, 20, 154-159.

41. Polidoro, B.A.; Carpenter, K.E.; Collins, L.; Duke, N.C.; Ellison, A.M.; Ellison, J.C.; Farnsworth, E.J.; Fernando, E.S.; Kathiresan, K.; Koedam, N.E.; et al. Mangrove extinction risk and geographic areas of global concern. PLoS One 2010, 5, e10095.

42. Valiela, I.; Bowen, J.L.; York, J.K. Mangrove forests: One of the world's threatened major tropical environments. Bioscience. 2001, 51, 807-815.

43. Wilkie, M.L.; Foruna, S. Status and Trends in Mangrove Area Extent Worldwide; Forest Resources Assessment Working Paper 63; Food and Agriculture Organization of the United Nations: Roma, Italy, 2003.

44. Giesen W.; Wulffraat, S.; Zieren, M.; Scholten, L. Mangrove Guidebook for Southeast Asia; Food and Agricultural Organisation and Wetlands International: Bangkok, Thailand, 2007.

45. Duke, N.C.; Meynecke, J.O.; Dittmann, S.; Ellison, A.M.; Anger, K.; Berger, U.; Cannicci, S.; Diele, K.; Ewel, K.C.; Field, C.D.; et al. A world without mangroves? Science 2007, 317, 41-42.

46. Spalding, M.; Kainuma, M.; Collins, L. World Atlas of Mangroves; Earthscan: London, UK, 2010.

47. Farnsworth, E.J.; Ellison, A.M. The global conservation status of mangroves. AMBIO 1997, 26, 328-334.

48. Primavera, J.H. Development and conservation of Philippine mangroves: Institutional issues. Ecol. Econ. 2000, 35, 91-106.

49. Dahdouh-Guebas, F. The use of remote sensing and GIS in the sustainable management of tropical coastal ecosystems. Environ. Dev. Sustain. 2002, 4, 93-112.

50. Primavera, J.H. Mangroves, fishponds, and the quest for sustainability. Science 2005, 310, 57-59.

51. Gopal, B.; Chauhan, M. Biodiversity and its conservation in the Sundarban Mangrove Ecosystem. Aquat. Sci. 2006, 68, 338-354.

52. Primavera, J.H. Overcoming the impacts of aquaculture on the coastal zone. Ocean Coast. Manag. 2006, 49, 531-545.

53. Gilman, E.L.; Ellison, J.; Duke, N.C.; Field, C. Threats to mangroves from climate change and adaptation options: A review. Aquat. Bot. 2008, 89, 237-250.

54. Walters, B.B.; Rönnbäck, P.; Kovacs, J.M.; Crona, B.; Hussain, S.A.; Badola, R.; Primavera, J.H.; Barbier, E.; Dahdouh-Guebas, F. Ethnobiology, socio-economics and management of mangrove forests: A review. Aquat. Bot. 2008, 89, 220-236.

55. Field, C.D. Impact of expected climate change on mangroves. Hydrobiologia 1995, 295, 75-81. 
56. Krauss, K.W.; Lovelock, C.E.; McKee, K.L.; Lopez-Hoffman, L.; Ewe, S.M.L.; Sousa, W.P. Environmental drivers in mangrove establishment and early development: A review. Aquat. Bot. 2008, 89, 105-127.

57. Chan, H.T.; Baba, S. Manual on Guidelines for Rehabilitation of Coastal Forests Damaged by Natural Hazards in the Asia-Pacific Region; International Society for Mangrove Ecosystems (ISME) and International Tropical Timber Organization (ITTO): Okinawa, Japan, 2009; p. 66.

58. Suzuki, T.; Zijlema, M.; Burger, B.; Meijer, M.C.; Narayan, S. Wave dissipation by vegetation with layer schematization in SWAN. Coast. Eng. 2012, 59, 64-71.

59. De la Cruz, A.A. Tropical wetlands as a carbon source. Aquat. Bot. 1986, 25, 109-115.

60. Hooijer, A.; Silvius, M.; Wösten, H.; Page, S. PEAT-CO2: Assessment of CO2 Emissions from Drained Peatlands in SE Asia, Delft Hydraulics, Report Q3943, 1st ed.; Wetlands International, Delft Hydraulics: Delft, The Netherlands, 2006.

61. Grimsditch, G.; Alder, J.; Nakamura, T.; Kenchington, R.; Tamelander, J. The blue carbon special edition-Introduction and overview. Ocean Coast. Manag. 2013, 83, 1-4.

62. United Nations Environmental Program. Global Environment Outlook Yearbook 2004; United Nations Environment Programme: Nairobi, Kenya, 2004.

63. Laffoley, D.; Grimsditch, G. The Management of Natural COASTAL Carbon Sinks; International Union for Conservation of Nature (IUCN): Gland, Switzerland, 2009; p. 53.

64. Nellemann, C.; Corcoran, E.; Duarte, C.M.; Valdés, L.; de Young, C.; Fonseca, L.; Grimsditch, G. Blue Carbon: The Role of Healthy Oceans in Binding Carbon-A Rapid Response Assessment. United Nations Environment Programme, GRID-Arendal, 2009. Available online: http://www.grida.no (accessed on 1 December 2012).

65. Gordon, D.; Murray, B.C.; Pendleton, L.; Victor, B. Financing Options for Blue Carbon: Opportunities and Lessons from the REDD+ Experience; Nicholas Institute Report; Nicholas Institute: Durham, NC, USA, 2011.

66. Ullman, R.; Bilbao-Bastida, V.; Grimsditch, G. Including blue carbon in climate market mechanisms. Ocean Coast. Manag. 2012, 83, 15-18.

67. Jones, T.G. Shining a light on Madagascar's mangroves. Madag. Conserv. Dev. 2013, 8, 4-6.

68. Heumann, B.W. Satellite remote sensing of mangrove forests: Recent advances and future opportunities. Prog. Phys. Geogr. 2011, 35, 87-108.

69. Manson, F.J.; Loneragan, N.R.; McLeod, I.M.; Kenyon, R.A. Assessing techniques for estimating the extent of mangroves: Topographic maps, aerial photographs, and Landsat TM images. Mar. Freshw. Res. 2001, 52, 787-792.

70. Ruiz-Luna, A.; Berlanga-Robles, C.A. Land use, land cover changes and coastal lagoon surface reduction associated with urban growth in northwest Mexico. Landsc. Ecol. 2003, 18, 159-171.

71. Cornejo, R.H.; Koedam, N.; Luna, A.R.; Troell, M.; Dahdouh-Guebas, F. Remote sensing and ethno- botanical assessment of the mangrove forest changes in the Navachiste-San Ignacio-Macapule lagoon complex, Sinaloa, Mexico. Ecol. Soc. 2005, 10, 16.

72. Beland, M.; Goita, K.; Bonn, F.; Pham, T.T.H. Assessment of land-cover changes related to shrimp aquaculture using remote sensing data: A case study in the Giao Thuy District, Vietnam. Int. J. Remote Sens. 2006, 27, 1491-1510. 
73. Giri, C.; Pengra, B.; Zhu, Z.L.; Singh, A.; Tieszen, L.L. Monitoring mangrove forest dynamics of the Sundarbans in Bangladesh and India using multi-temporal satellite data from 1973 to 2000. Estuar. Coast. Shelf Sci. 2007, 73, 91-100.

74. Giri, C.; Zhu, Z.; Tieszen, L.L.; Singh, A.; Gillette, S.; Kelmelis, J.A. Mangrove forest distributions and dynamics (1975-2005) of the tsunami-affected region of Asia. J. Biogeogr. 2008, 35, 519-528.

75. Liu, K.; Li, X.; Shi, X.; Wang, S.G. Monitoring mangrove forest changes using remote sensing and GIS data with decision-tree learning. Wetlands 2008, 28, 336-346.

76. Paling, E.I.; Kobryn, H.T.; Humphreys, G. Assessing the extent of mangrove change caused by Cyclone Vance in the eastern Exmouth Gulf, northwestern Australia. Estuar. Coast. Shelf Sci. 2008, 77, 603-613.

77. Alsaaideh, B.; Al-Hanbali, A.; Tateishi, R.; Kobayashi, T.; Hoan, N.T. Mangrove forests mapping in the southern part of Japan using Landsat ETM+ with DEM. J. Geogr. Inf. Syst. 2013, 5, 369-377.

78. Li, M.S.; Mao, L.J.; Shen, W.J.; Liu, S.Q.; Wei, A.I. Change and fragmentation trends of Zhanjiang mangrove forests in southern China using multi-temporal Landsat imagery (1977-2010). Estuar. Coast. Shelf Sci. 2013, 130, 111-120.

79. Nguyen, H.; McAlpine, C.; Pullar, D.; Johansen, K.; Duke, N. The relationship of spatial-temporal changes in fringe mangrove extent and adjacent land-use: Case study of Ken Giang coast, Vietnam. Ocean Coast. Manag. 2013, 76, 12-22.

80. Giri, C.; Muhlhausen, J. Mangrove forest distributions and dynamics in Madagascar (1975-2005). Sensors 2008, 8, 2104-2117.

81. Rasolofoharinoro, M.; Blasco, F.; Bellan, M.F.; Aizpuru, M.; Gauquelin, T.; Denis, J. A remote sensing based methodology for mangrove studies in Madagascar. Int. J. Remote Sens. 1998, 19, 1873-1886.

82. Pasqualini, V.; Iltis, J.; Dessay, N.; Lointier, M.; Guelorget, O.; Polidori, L. Mangrove mapping in North-Western Madagascar using SPOT-XS and SIR-C radar data. Hydrobiologia 1999, 413, $127-133$.

83. Guillet, M.; Renou, E.; Robin, M.; Debaine, F.; Ratsivalaka, S. Suivi et analyze de l'evolution de la mangrove de Mahajamba (Nord-ouest de Madagascar). In Proceedings of the International Pluridisciplinary Conference, Lille, France, 16-18 January 2008.

84. Raharimahefa, T.; Kusky, T.M. Environmental monitoring of Bombetoka Bay and the Betsiboka Estuary, Madagascar, using multi-temporal satellite data. J. Earth Sci. 2010, 21, 210-226.

85. Rakotomavo, A.; Fromard, F. Dynamics of mangrove forests in the Mangoky River delta, Madagascar, under the influence of natural and human factors. For. Ecol. Manag. 2010, 259, 1161-1169.

86. Giri, C. National-Level Mangrove Cover Data-Sets for 1990, 2000 and 2010; United States Geological Survey: Sioux Falls, SD, USA, 2011.

87. Rasolofo, M.V.; Ramilijaona, O. Variability in the abundance and recruitment of Fenneropenaeus indicus and Metapenaeus monoceros postlarvae and juveniles in Ambaro Bay mangroves of Madagascar. Nat. Faune 2009, 24, 103-109. 
88. Rasofolo, M.V. Use of mangroves by traditional fishermen in Madagascar. Mangroves Salt Marshes 1997, 1, 243-253.

89. Mayaux, P.; Gond, V.; Bartholome, E. A near-real time forest-cover map of Madagascar derived from SPOT-4 VEGETATION data. Int. J. Remote Sens. 2000, 21, 3139-3144.

90. Critical Ecosystem Partnership Fund (CEPF). Madagascar Vegetation Mapping Project; CEPF: Arlington, VA, USA, 2007.

91. Harper, G.J.; Steininger, M.K.; Tucker, C.J.; Juhn, D.; Hawkins, F. Fifty years of deforestation and forest fragmentation in Madagascar. Environ. Conserv. 2007, 34, 325-333.

92. USGS Earth Explorer. Available online: http://http://earthexplorer.usgs.gov/ (accessed on 1 December 2011).

93. Gutman, G.; Byrnes, R.; Masek, J.; Covington, S.; Justice, C.; Franks, S.; Kurtz, R. Towards monitoring land-cover and land-use changes at a global scale: The Global Land Survey 2005. Photogramm. Eng. Remote Sens. 2008, 74, 6-10.

94. Chavez, P.S. Image-based atmospheric corrections: Revisited and improved. Photogramm. Eng. Remote Sens. 1996, 62, 1025-1036.

95. Kirui, K.B.; Kairo, J.G.; Bosire, J.; Viergever, K.M.; Rudra, S.; Huxham, M.; Briers, R.A. Mapping of mangrove forest land cover change along the Kenya coastline using Landsat imagery. Ocean Coast. Manag. 2013, 83, 19-24.

96. Simard, M.; Zhang, K.Q.; Rivera-Monroy, V.H.; Ross, M.S.; Ruiz, P.L.; Castaneda-Moya, E.; Twilley, R.R.; Rodriguez, E. Mapping height and biomass of mangrove forests in Everglades National Park with SRTM elevation data. Photogramm. Eng. Remote Sens. 2006, 72, 299-311.

97. Fatoyinbo, T.E.; Simard, M.; Washington-Allen, R.A.; Shugart, H.H. Landscape-scale extent, height, biomass, and carbon estimation of Mozambique's mangrove forests with Landsat ETM+ and Shuttle Radar Topography Mission elevation data. J. Geophys. Res. Biogeosci. 2008, 113, doi:10.1029/2007JG000551.

98. Simard, M.; Rivera-Monroy, V.H.; Mancera-Pineda, J.E.; Castaneda-Moya, E.; Twilley, R.R. A systematic method for 3D mapping of mangrove forests based on Shuttle Radar Topography Mission elevation data, ICEsat/GLAS waveforms and field data: Application to Cienaga Grande de Santa Marta, Colombia. Remote Sens. Environ. 2008, 112, 2131-2144.

99. Bhattarai, B.; Giri, C. Assessment of mangrove forests in the Pacific region using Landsat imagery. J. Appl. Remote Sens. 2011, doi:10.1117/1.3563584.

100. Long, J.B.; Giri, C. Mapping the Philippines' mangrove forests using Landsat imagery. Sensors 2011, 11, 2972-2981.

101. Fatoyinbo, T.E.; Simard, M. Height and biomass of mangroves in Africa from ICESat/GLAS and SRTM. Int. J. Remote Sens. 2013, 34, 668-681.

102. Blasco, F.; Gauquelin, T.; Rasolofoharinoro, M.; Denis, J.; Aizpuru, M.; Caldairou, V. Recent advances in mangrove studies using remote sensing data. Mar. Freshw. Res. 1998, 49, 287-296.

103. Tomlinson, P.B. The Botany of Mangroves; Cambridge University Press: Melbourne, Australia, 1986.

104. Aschbacher, J.; Ofren, R.; Delsol, J.P.; Suselo, T.B.; Vibulsresth, S.; Charrupat, T. An integrated comparative approach to mangrove vegetation mapping using advanced remote sensing and GIS technologies: Preliminary results. Hydrologica 1995, 295, 285-295. 
105. Gao, J.A. Hybrid method toward accurate mapping of mangroves in a marginal habitat from SPOT Multispectral data. Int. J. Remote Sens. 1998, 19, 1887-1899.

106. Green, E.P.; Clark, C.D.; Mumby, P.J.; Edwards, A.J.; Ellis, A.C. Remote sensing techniques for mangrove mapping. Int. J. Remote Sens. 1998, 19, 935-956.

107. Gao, J.A. Comparative study on spatial and spectral resolutions of satellite data in mapping mangrove forests. Int. J. Remote Sens. 1999, 20, 2823-2833.

108. Saito, H.; Bellan, M.F.; Al-Habshi, A.; Aizpuru, M.; Blasco, F. Mangrove research and coastal ecosystem studies with SPOT-4 HRVIR and TERRA ASTER in Arabian Gulf. Int. J. Remote Sens. 2003, 24, 4073-4092.

109. Tong, P.H.; Auda, Y.; Populus, J.; Aizpura, M.; Habshi, A.A.; Blasco, F. Assessment from space of mangroves evolution in the Mekong Delta, in relation to extensive shrimp farming. Int. J. Remote Sens. 2004, 25, 4795-4812.

110. Jensen, L.S.; Mueller, T.; Tate, K.R.; Ross, D.J.; Magid, J.; Nielsen, N.E. Soil surface $\mathrm{CO}_{2}$ flux as an index of soil respiration in situ: A comparison of two chamber methods. Soil Biol. Biochem. 1996, 28, 1297-1306.

111. Fromard, F.; Puig, H.; Mougin, E.; Marty, G.; Betoulle, J.L.; Cadamuro, L. Structure, above-ground biomass and dynamics of mangrove ecosystems: New data from French Guiana. Oecologia 1998, 115, 39-53.

112. Smith, T.J., III; Whelan, K.R.T. Development of allometric relations for three mangrove species in South Florida for use in the Greater Everglades Ecosystem restoration. Wetl. Ecol. Manag. 2006, 14, 409-419.

113. Komiyama, A.; Poungparn, S.; Kato, S. Common allometric equations for estimate the tree weight of mangroves. J. Trop. Ecol. 2005, 21, 471-477.

114. Schumacher, B. Methods for the Determination of Total Organic Carbon (TOC) in Soils and Sediments; Ecological Risk Assessment Support Center, Office of Research and Development. US Environmental Protection Agency: Washington, DC, USA, 2002.

115. Mikhailova, E.A.; Noble, R.R.P.; Post, C.J. Comparison of soil organic carbon recovery by Walkley-Black and dry combustion methods in the Russian Chernozem. Commun. Soil Sci. Plant Anal. 2003, 34, 1853-1860.

116. De Vos, B.; Letterns, S.; Muys, B.; Deckers, J.A. Walkley-Black analysis of forest soil organic carbon: Recovery, limitations and uncertainty. Soil Use Manag. 2007, 23, 221-229.

117. Meersmans, J.; van Wesemael, B.; van Molle, M. Determining soil organic carbon for agricultural soils: A comparison between the Walkley \& Black and the dry combustion methods (north Belgium). Soil Use Manag. 2009, 25, 346-353.

118. Simpson, W.T. Method to Estimate Dry-Kiln Schedules and Species Groupings: Tropical and Temperate Hardwoods; US Department of Agriculture, Forest Service, Forest Products Laboratory: Washington, DC, USA, 1996.

119. Dharmawan, I.W.S.; Siregar, C.A. Soil carbon and carbon estimation of Avicennia marina (Forsk.). Vierh. Stand at Ciasem, Purwakarta. J. Penelit. Hutan dan Konservasi Alam. 2008, 5, 317-328.

120. Clough, B.F.; Scott, K. Allometric relationships for estimating above-ground biomass in six mangrove species. For. Ecol. Manag. 1989, 27, 117-127. 
121. Comley, B.W.T.; McGuinness, K.A. Above- and below-ground biomass, and allometry, of four common northern Australian mangroves. Aust. J. Bot. 2005, 53, 431-436.

122. Sinclair, T.T.; Hoffer, R.M.; Schreiber, M.M. Reflectance and internal structure of leaves from several crops during a growing season. Agron. J. 1971, 63, 864-868.

123. Elvidge, C.D. Visible and near-infrared reflectance characteristics of dry plant materials. Int. J. Remote Sens. 1990, 11, 1775-1795.

124. Curran, P.J. Remote sensing of foliar chemistry. Remote Sens. Environ. 1989, 30, 271-278.

125. Tamura, M.; Kikushima, K. Extraction of mangrove forests using a satellite image and a digital elevation model. In Proceedings of the SPIE 7104, Remote Sensing for Agriculture, Ecosystems, and Hydrology X, Cardiff, UK, 15 September 2008; Volume 7104.

126. Lippitt, C.D.; Rogan, J.; Zhe, L.; Eastman, R.J.; Jones, T.G. Mapping selective logging in mixed deciduous forest: A comparison of machine learning algorithms. Photogramm. Eng. Remote Sens. 2008, 74, 1201-1211.

127. Plugge, D.; Baldauf, T.; Ratsimba, H.R.; Rajoelison, G.; Köhl, M. Combined biomass inventory in the scope of REDD (Reducing Emissions from Deforestation and Forest Degradation. Madag. Conserv. Dev. 2010, 5, 23-34.

128. Bredbenner, A. Profiles in Blue Carbon Field Work; Conservation International: Washington, DC, USA, 2013.

(C) 2014 by the authors; licensee MDPI, Basel, Switzerland. This article is an open access article distributed under the terms and conditions of the Creative Commons Attribution license (http://creativecommons.org/licenses/by/3.0/). 